\title{
Pseudothurmanniid ammonites from quarries near Lietavská Lúčka and their stratigraphical significance (Late Hauterivian, Central Western Carpathians, Slovakia)
}

\author{
Zdeněk VAŠíČEK ${ }^{1, *}$ and Ondřej MALEK ${ }^{2}$ \\ 1 Academy of Sciences of the Czech Republic, Institute of Geonics, Studentská 1768, 70800 Ostrava-Poruba, Czech \\ Republic \\ 2 Green Gas DPB, a.s. Rudé armády 637, 73921 Paskov, Czech Republic
}

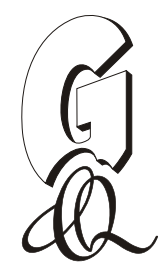

Vašíček, Z., Malek, O., 2017. Pseudothurmanniid ammonites from quarries near Lietavská Lúčka and their stratigraphical significance (Late Hauterivian, Central Western Carpathians, Slovakia). Geological Quarterly, 61 (3): 613-631, doi: 10.7306/gq.1364

\begin{abstract}
Pseudothurmanniid ammonites within Upper Hauterivian calcareous deposits are present in quarries on Polomec Hill near the village of Lietavská Lúčka, Slovakia. These deposits belong to the Mráznica Formation of the Krížna Nappe that is a part of the Fatricum Unit in the Central Western Carpathians. Nine ammonite species are described in detail, one of which, Binelliceras michalíki, is new. The species identified indicate the Upper Hauterivian Balearis and Ohmi ammonite zones. The zone of the uppermost Hauterivian, Catulloi Zone, is not documented as far as pseudothurmanniid ammonites are concerned. The lack of developmentally younger representatives of the pseudothurmanniid ammonites neither in the studied locality, nor in other Slovak localities, is explained by marked changes in the northern Tethyan margin in Europe during the latest Hauterivian.
\end{abstract}

Key words: ammonites, taxonomy, stratigraphy, Hauterivian, Western Carpathians.

\section{INTRODUCTION}

In the course of basic geological survey work organised by the Geological Institute of the Slovak Academy of Sciences in Bratislava and led by J. Michalík at the end of the last millennium, Slovak colleagues together with one of us (Z. V.) recorded and documented several exposures in the Neocomian deposits of the Krížna Nappe in the Strážov Mountains. In the exposures, ammonites usually then termed Pseudothurmannia were dominant. In this paper, we call these pseudothurmanniid ammonites.

The richest locality with the best-preserved pseudothurmanniid ammonites was a group of quarries on Polomec Hill near the village of Lietavská Lúčka. In these quarries, marly limestones have been exploited commercially as a raw material for the cement works at Lietavská Lúčka. A subsequent collection of these ammonites was then studied taxonomically, based on the state of knowledge current then (Adamíková et al., 1983; Vašíček and Michalík, 1988; Vašíček et al., 1994).

\section{* Corresponding author, e-mail: zdenek.vasicek@ugn.cas.cz}

Received: January 28, 2017; accepted: April 9, 2017; first published online: June 19, 2017
Hoedemaeker (2013) published, based on extensive material, a significant monograph containing a thorough review of previous knowledge with a huge amount of data and a new approach to the genus Pseudothurmannia and the related "genera" designated by him also as Crioceratites, mimicking Pseudothurmannia. An important element of his original taxonomic concept was the study of sculpture development on juvenile whorls of these ammonites. The method used and the results published by Hoedemaeker (2013) became the stimulus for our return to the study of the collection of pseudothurmanniid ammonites from Lietavská Lúčka. All fossils collected from the quarries on Polomec Hill are deposited in the Geological Pavilion of the Vysoká škola báňská - Technical University of Ostrava.

In the Lower Cretaceous of the Mediterranean area, the pseudothurmanniid ammonites are significant within the Upper Hauterivian, ammonite zones and subzones based on their occurrence (e.g., Company et al., 2003; Vermeulen, 2004; Hoedemaeker, 2013; Reboulet et al., 2014). These ammonites were associated with a pelagic marine environment, and can be found mainly in the deep-water deposits of the continental slope.

The section and lithofacies of the Lower Cretaceous deposits exposed on Polomec Hill, together with the occurrence of important micro- and macrofossils, was shown in figure 20 of Vašíček et al. (1994). Fossiliferous limestones with pseudothurmanniid ammonites were determined by Borza et al. (1984) as Hauterivian/Barremian boundary beds. At that time it was 


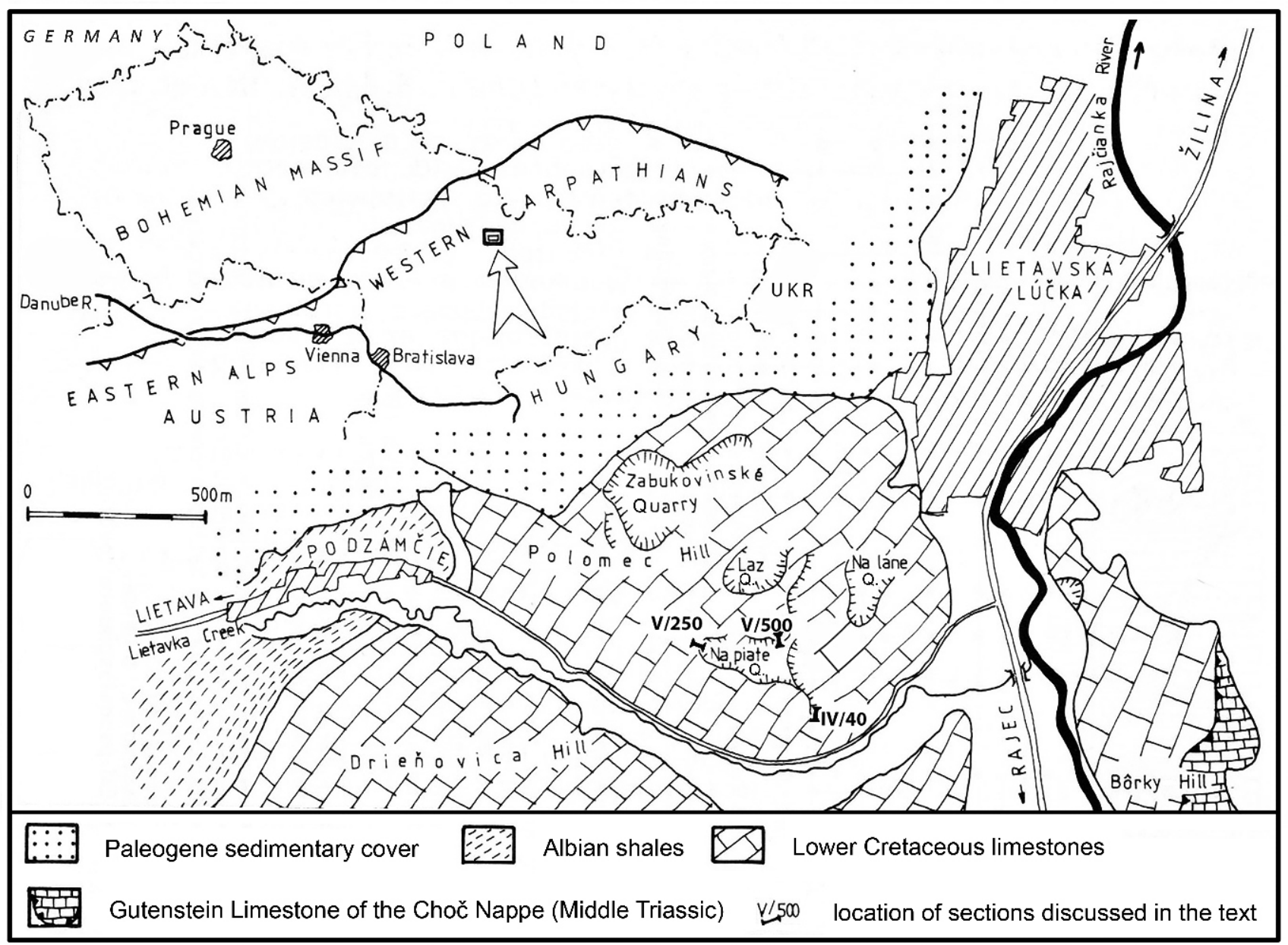

Fig. 1. Geographical position and geological situation of the Lietavská Lúčka area (modified after Borza et al., 1984)

assumed that the ammonites represented also the lowermost Barremian. Later the term Pseudothurmannia Beds or more precisely Pseudothurmannia horizon was used.

\section{GEOLOGICAL SETTING}

The group of abandoned quarries situated on Polomec Hill near Lietavská Lúčka ( 8 km south-southwest of the southern edge of Žilina) belongs to the Lower Cretaceous Mráznica Formation of the Križna Nappe in the Fatricum Unit in the Central Western Carpathians (Fig. 1). For a long time, sediments of that place were mined as a raw material for cement production by the company Povážské cementárne Lietavská Lúčka. In 1998, mining as well as production of cement ceased there and since then sections, formerly exposed favourably in quarry walls, have become increasingly degraded.

Pelagic limestones with pseudothurmanniid ammonites as described here are illustrated in Figure 2. In the bottom part of the deposits studied, there are grey, commonly thin-bedded, marly limestones. They are followed by marly platy limestones: mainly light, olive-brown limestones intercalated with light grey, green and red limestones, which are often blotched. In the upper part of the succession studied, there are light grey marly limestones.

A more detailed lithological description of documented sections and macrofaunal and microfaunal characteristics may be found in Adamíková et al. (1983), Vašíček and Michalík (1988) and Vašíček et al. (1994).

Fossiliferous deposits in the body of the Križna Nappe are folded and above all considerably affected by nappe tectonics (see fig. 2C in Vašíček and Michalík, 1988). Although extensive walls of the quarries on Polomec Hill formerly showed good exposure, no continuous sequence of strata could be documented. A somewhat idealized section through the whole sequence of strata was constructed based on documentation of all levels in the quarries (Vašiček et al., 1994, fig. 20), within which pseudothurmanniid ammonites occur mainly in three partial sections. The stratigraphically older section is a partial section on level IV; the remaining two, approximately equivalent sections occur on level V of Na piate Quarry, at levels 250 and $500 \mathrm{~m}$ from the entry to level $\mathrm{V}$ (see Fig. 1).

\section{MATERIAL PRESERVATION}

The ammonites occur within marly micritic limestones. Given a moderately high proportion of clay minerals, the deposits have undergone significant compaction. Hence, the ammonite shells are compressed in the plane of the bedding. Locally there is slight deformation due to lateral pressure. The great majority of specimens are preserved as sculpture moulds, specimens with imperfectly preserved remains of sutures occurring only exceptionally. In the collection of several hundred 

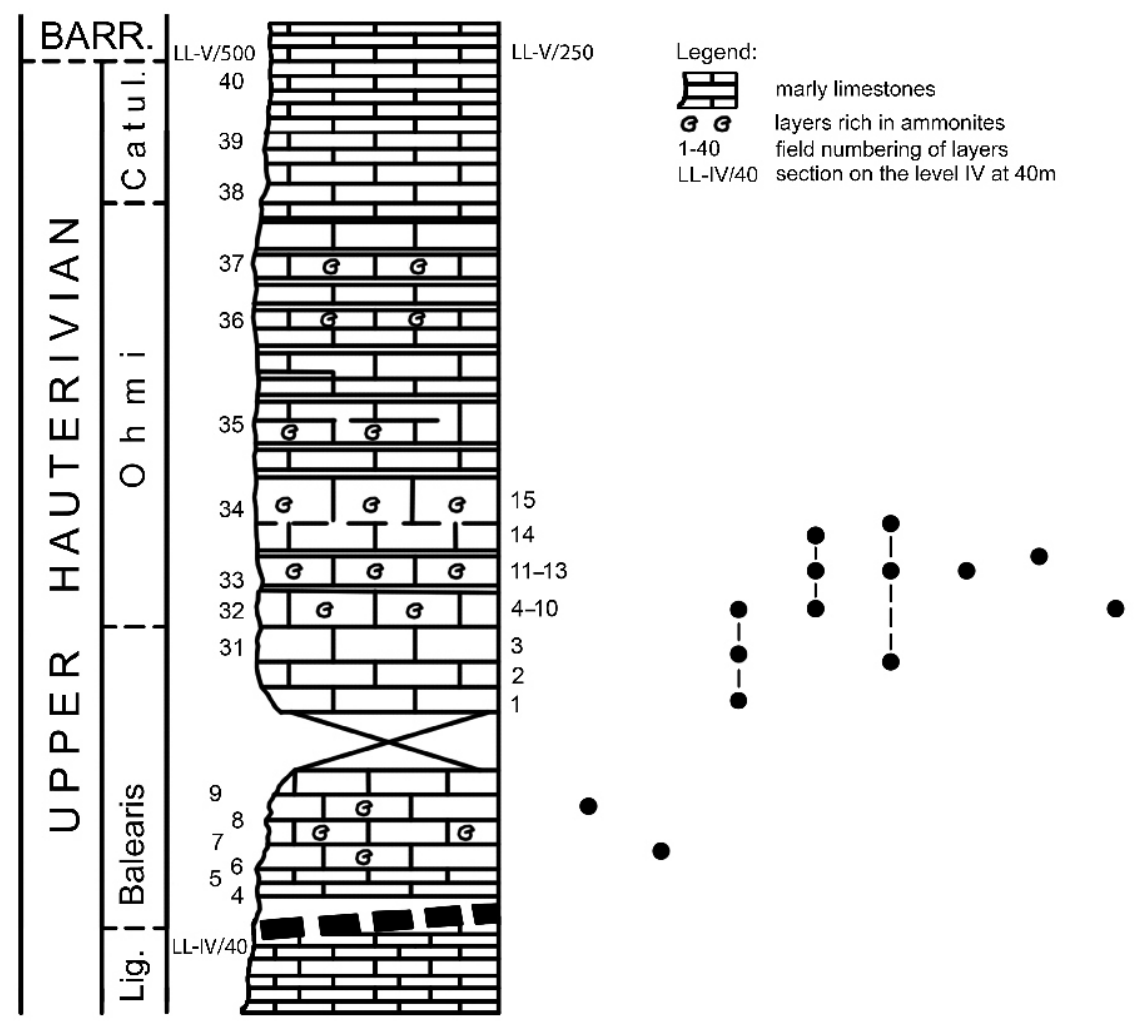

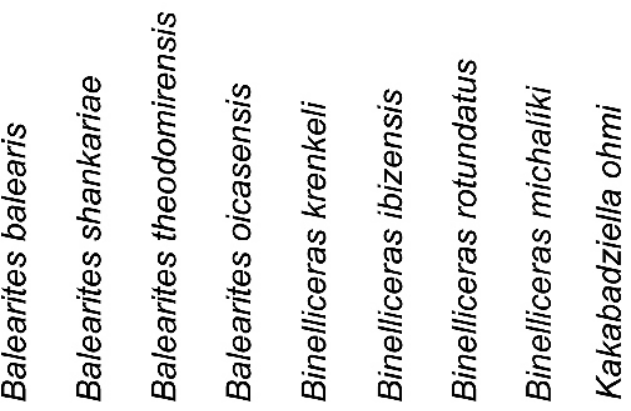

Fig. 2. Distribution of ammonite species determined around Polomec Hill near Lietavská Lúčka

specimens from the quarries near Lietavská Lúčka, in only 30 are the earliest whorls preserved favourably. In the remaining specimens, only adult whorls are well-preserved. The specimens collected are rather small, shell diameters being usually $\sim 40$ to $60 \mathrm{~mm}$. Exceptional specimens reaching $\sim 100 \mathrm{~mm}$ occur in the sections on Level 5.

\section{METHODOLOGY}

The initial study of pseudothurmanniid ammonites following Hoedemaeker (2013) involves observation of the development of the sculpture in the earliest stages of shells, up to a diameter of $\sim 30$ to $\sim 40 \mathrm{~mm}$. The beginning of the first whorl with the initial chamber has never been found in our material. In rare cases only the second half of the first whorl is preserved imperfectly.

For the taxonomic study, it is necessary to observe in the early whorls whether the first ribs are thin or strong, closely or widely spaced, and whether the ribs bear tubercles or not. If tubercles are developed, they can occur in three categories: umbilical tubercles, lateral tubercles and ventrolateral tubercles.
Their shape and size (bullate, conical and clavate) are significant. The density of ribbing is also important. On the ribs, the appearance of the first tubercles, especially of the lateral ones, their disappearance, the extent of a given style of ribbing depending on shell diameter, and its extinction and potential replacement by another character of ribbing are observed. The ventrolateral tubercles usually end in short spines; however, more frequently only their bases in the form of tubercles are preserved. Another factor observed is a differentiation between the main and inserted ribs. The main ribs may be accompanied by constrictions. What is also essential is whether juvenile whorls are in contact with each other or are poorly developed, which cannot always be seen clearly if shells are deformed.

In most cases, the earliest whorls are imperfectly preserved, corroded, and also badly exposed, sometimes after unsuccessful mechanical preparation. Not all juvenile specimens could be included in our taxonomic analysis. We used specimens that could be interconnected with each other, including subadult to adult specimens which made it possible to observe ontogenesis.

The specimens selected, with favourably preserved juvenile whorls, were photographed first. For photographing of juvenile 


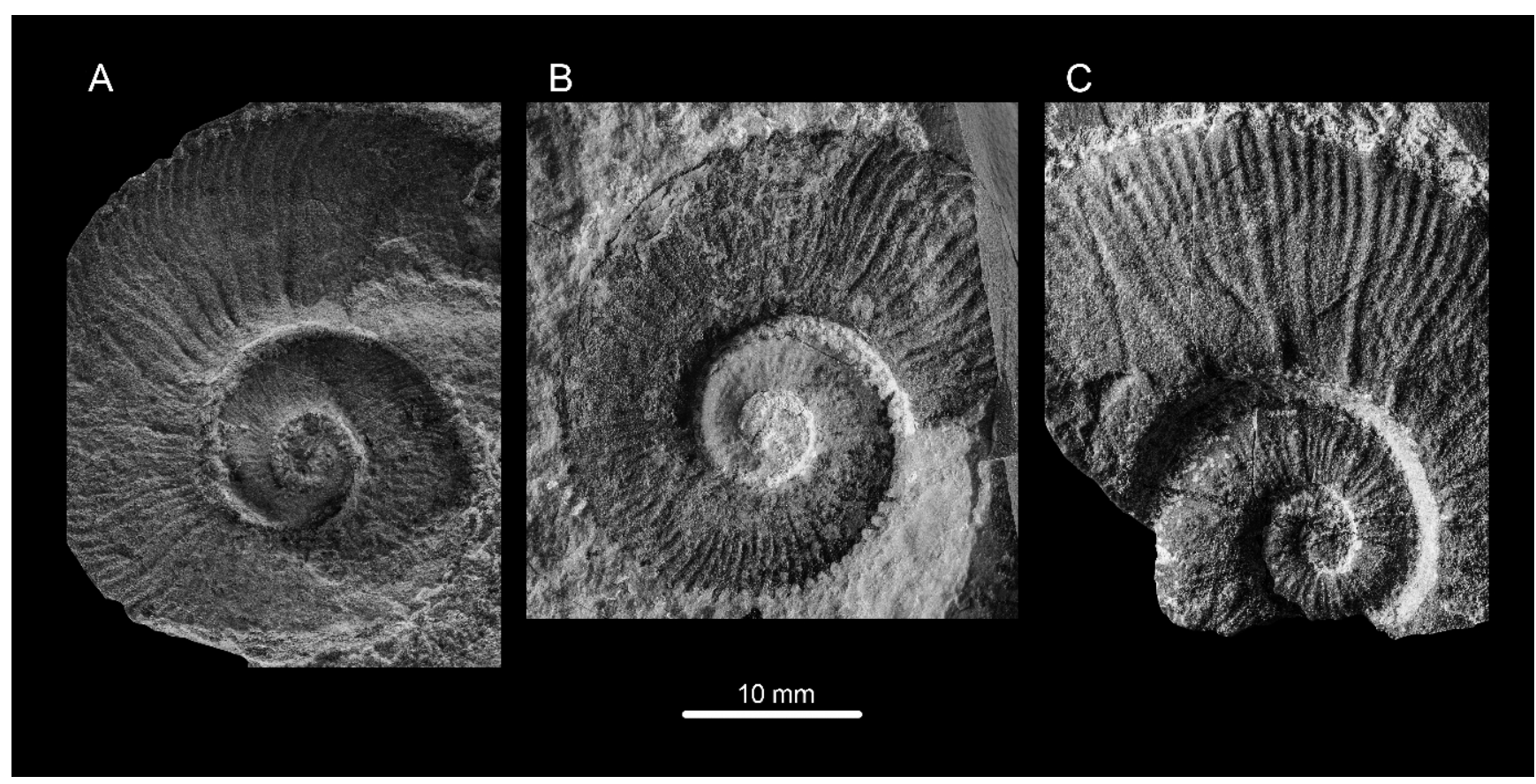

Fig. 3. Ribbing of the juvenile whorls

A - Balearites shankariae Sarkar, 1955, spec. SNM Z 21145; B - Balearites oicasensis Hoedemaeker, 2013, spec. SNM Z 38611; C - Binelliceras rotundatus Sarkar, 1955, spec. SNM Z 38621; photos of O. Malek

whorls a DSLR Canon EOS $70 D$ camera was used along with the Canon EF-S 60mm f/2,8 Macro USM lens which suits best this kind of macrophotography. Each specimen was put in a macrophotography light box with translucent sides that diffuses the light coming from multiple sources so that a soft light on the specimen is achieved. The specimen was installed on the pad in the light box so that the area of interest was perpendicular towards the lens surface. The camera was placed on a tripod and, via a camera Wi-Fi connection through mobile $L G G 3$ with EOS Remote Canon software, a series of photographs were taken. For a perfectly sharp photograph, it was necessary to take about twenty pictures with different manually chosen focus points, with the same camera setting without any move. This technique is known as focus stacking and is useful in macrophotography because it increases the depth of the field. Adobe Photoshop and Adobe Lightroom software were used for all the post processing work. In the Adobe Photoshop software, a series of images was uploaded and through the correct setting options, the sharpest part from every photograph was selected so that the final picture was constructed only from the best parts. Subsequent improvements were made with Adobe Lightroom and the final black background was created in Adobe Photoshop. The results of this technique are shown in Figure 3.

Photos enlarged to the required size have shown that the earliest whorls are not usually preserved perfectly; they cannot normally be seen sufficiently distinctly. For this reason, they were drawn. Sarkar (1955) used a similar method. His drawings that omit juvenile whorls are, however, too schematic. Our drawings of juvenile whorls illustrate only that which can be seen on the specimens, i.e. what is preserved. In the course of drawing the juvenile whorls, we avoided idealization, reconstruction and supplementation of missing parts of the sculpture.
With regard to the non-uniform scale of the original drawings, all specimens drawn were converted to a uniform scale to facilitate their correlation (see Fig. 4).

\section{SYSTEMATIC PALAEONTOLOGY}

The sections in Lietavská Lúčka are not sufficiently complete and the collected material is not sufficiently rich to observe in detail the phylogenesis of the species represented as in Hoedemaeker (2013). This paper is thus based on the framework of Hoedemaeker (2013) and, in addition to historical and old sources, takes into account recent taxonomic work on crioceratid and pseudothurmannid ammonites (e.g., Busnardo, 2003; Vermeulen, 2004; Vermeulen et al., 2009).

The synonymies provided here include only the initial paper with the first description and figuring of the species under study, the most recent papers, and those that are of regional significance or of importance to the discussion. They also contain our opinions and revisions concerning the taxonomic position of species earlier described from Slovak localities and remarks on some minor discrepancies in synonymies in Hoedemaeker (2013). An exception is in the extensive synonymies of $B$. balearis and $B$. shankariae provided, with reference to the difference between our concept and the concept of Hoedemaeker (2013). Their basis, however, was the synonymies compiled by Hoedemaeker (2013).

For the size parameters of ammonite shells, which are always somewhat affected by slight compression in the plane of the bedding, the following abbreviations are used: $\mathrm{D}$ - shell diameter (Dmax - maximum preserved diameter), $\mathrm{H}$ - whorl height and $U$ - umbilicus diameter. Parameter B (breadth of 

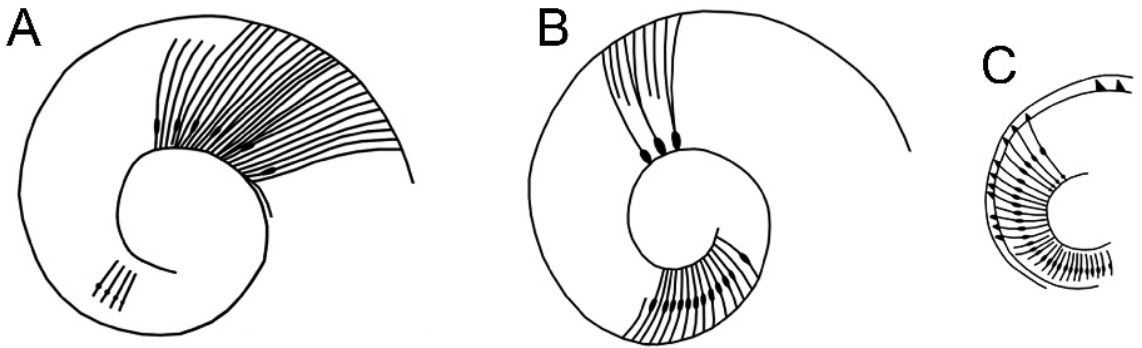

$10 \mathrm{~mm}$
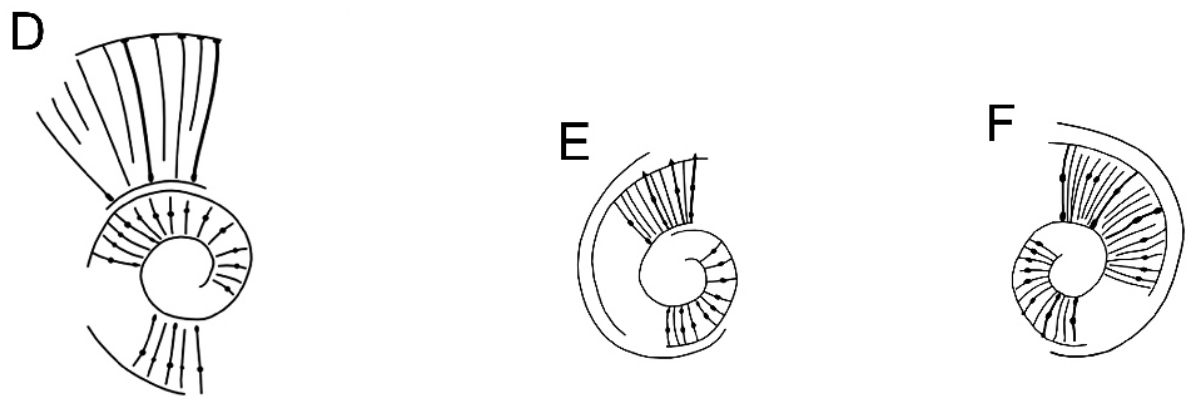

Fig. 4. Drawings of juvenile whorls

A - Balearites shankariae Sarkar, 1955, spec. SNM Z 21145; B - Balearites theodomirensis Hoedemaeker, 2013, spec. SNM Z 38605; C - Balearites oicasensis Hoedemaeker, 2013, spec. SNM Z 38611; D - Binelliceras krenkeli (Sarkar, 1955), spec. SNM Z 38613; E - Binelliceras ibizensis (Wiedmann, 1962), spec. SNM Z 38619; F- Binelliceras rotundatus Sarkar, 1955; spec. SNM Z 38621

whorl) is not measurable. Ratios of the parameters measured to shell diameter (H/D, U/D) are indicated in brackets. It is necessary to emphasise that as more specimens of a species became available, we tried to take as many measurements as possible at various diameters of shells to find changes in the values of $H / D$ and $U / D$ depending upon shell diameter (the "egression" of Hoedemaeker, 2013), i.e. when a hitherto lower value of $H / D$ in comparison with that of $U / D$ increased and vice versa. Diagnostically, the turning point of both values is significant, i.e. when $H / D=U / D$. Where possible, we calculated the density of ribs near the umbilicus (UR) and ventrolaterally (VR) given per half-whorl related to the relevant, i.e. larger, height of the whorl.

The specimens analysed have curation numbers of the Slovak National Museum in Bratislava.

We consider the subgenera of the genus Crioceratites (Balearites and Binelliceras) in the concept by Hoedemaeker (2013) as individual genera (as in many previous papers, e.g. starting from Sarkar, 1954). In contrast to Hoedemaeker (2013), we decided, based on the first occurrence of the genus Crioceratites Léveillé, 1837 and later appearance of the genus Pseudothurmannia Spath, 1923, to put the genus Pseudothurmannia in the systematic part at the end of the taxonomy.

Suborder Ancyloceratina Wiedmann, 1966

Superfamily Ancyloceratoidea Gill, 1871

Family Ancyloceratidae Gill, 1871

Subfamily Crioceratitinae Gill, 1871

Genus Balearites Sarkar, 1954
T y p e s p e c i e s. - Crioceras baleare Nolan, 1894, by original designation of Sarkar (1954).

$\mathrm{R}$ e $\mathrm{m}$ a r k s. - Whorls are in contact or are, at most, negligibly developed, thin and densely ribbed. The innermost whorl is in a short section covered by trituberculate ribs, of which most frequently only lateral tubercles are preserved. On the inner and also on the following whorls, small, uniform ventrolateral tubercles occur. In the adult stage, the main ribs with umbilical tubercles accompanied by constrictions are stronger.

Balearites balearis (Nolan, 1894)

(Fig. 5A)

1860 Ancyloceras hillsi d'Orbigny; Ooster: p. 62, pl. 52, fig. 1. 1894 Crioceras baleare n. sp.; Nolan: p. 193, pl. 10, fig. 2 a, b (holotype).

1901 Hoplites balearis Nolan; Sarasin and Schöndelmayer: p. 87 , pl. 10 , fig. 4

1954 Crioceras baleare Nolan; Sarkar: p. 98.

1957 Balearites balearensis (Nolan); Arkell et al.: p. L208, fig. 238, 1 a,b (holotype).

1958 Balearites balearis (Nolan); Luppov and Drushchits: p. 102 , pl. 46 , fig. 8 a,b (holotype).

non 1960 Balearites balearis (Nolan); Drushchits and Kudryavtsev: p. 291, pl. 33, figs. 2, 3 (= Pseudothurmannia /Pseudothurmannia/ crimensis Wiedmann).

1962 Crioceratites (Pseudothurmannia) balearis balearis (Nolan); Wiedmann: p. 128, pl. 8, fig. 5, pl. 9, fig. 1.

non 1964 Balearites balearis (Nolan); Fülöp: pl. 27, fig. 7 (= ?Binelliceras binelli Astier). 


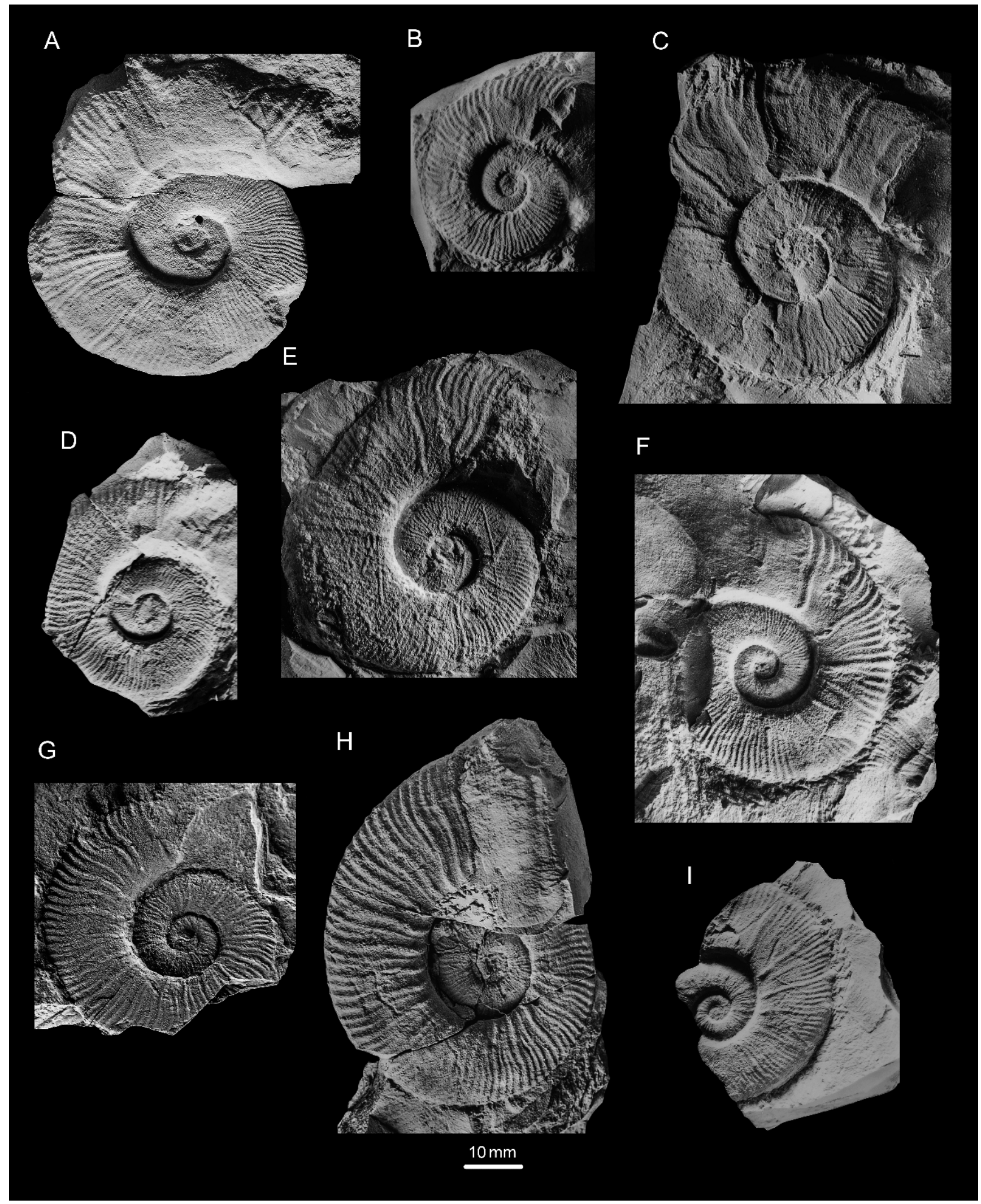

Fig. 5A - Balearites balearis (Nolan, 1894), spec. SNM Z 21143, level IV at 40 m, layer No. 8, Balearis ammonite Zone; B - Balearites theodomirensis Hoedemaeker, 2013, spec. SNM Z 38605 (m) with easily visible ventrolateral tubercles (in the lower part of the picture), level V at $250 \mathrm{~m}$, layer 1, Balearis/Ohmi Zone; C - Balearites theodomirensis Hoedemaeker, 2013, spec. SNM Z 38606 (M.), level V at $250 \mathrm{~m}$, Ohmi Zone; D - Balearites oicasensis Hoedemaeker, 2013, spec. SNM Z 38612, level V at $250 \mathrm{~m}$, layer 14, Ohmi Zone; E - Balearites oicasensis Hoedemaeker, 2013, adult spec. SNM Z 21144, level V at 500 m, layer 33, Ohmi Zone; F-Binelliceras krenkeli (Sarkar, 1955), spec. SNM Z 38615, level V at 250 m, layer 13, Ohmi Zone; G - Binelliceras ibizensis (Wiedmann, 1962), spec. SNM Z 38620, level V at $250 \mathrm{~m}$, layer 13, Ohmi Zone; H - Binelliceras ibizensis (Wiedmann, 1962), spec. SNM Z 38619, level V at $250 \mathrm{~m}$, layer 12, Ohmi Zone; I - Binelliceras rotundatus Sarkar, 1955, spec. SNM Z 38621, level V at $250 \mathrm{~m}$, debris, Ohmi Zone; all figured and described specimens will be deposited in the Slovak National Museum (Bratislava) under inventory numbers with the prefix SNM Z 
1978 Crioceratites (Crioceratites) balearis (Nolan); Immel: p. 46 , tab. 6 b (holotype), ?pl. 2, fig. 2 (= Crioceratites /Crioceratites/ ex gr. balearis (Nolan).

non 1981 Pseudothurmannia (Balearites) balearis (Nolan); Kakabadze: p. 91, pl. 19, figs. 3-5 (= Balearites theodomirensis Hoedemaeker).

non 1993 Balearites balearis (Nolan); Autran: pl. 13, fig. 4 (= Balearites theodomirensis Hoedemaeker).

1994 Pseudothurmannia balearis (Nolan); Vašíček et al.: p. 66, pl. 19, fig. 3, non pl. 19, fig. 4 (= Balearites oicasensis Hoedemaeker).

1995 Pseudothurmannia balearis (Nolan); Vašíček: p. 174, pl. 3, fig. 3.

non 1995 Pseudothurmannia (Balearites) balearis (Nolan); Vašíček: p. 174, pl. 4, fig. 5 (= Balearites oicasensis Hoedemaeker).

?1995 Crioceratites balearis (Nolan); Avram: pl. 6, fig. 4.

1996 Pseudothurmannia baleare (Nolan); Wright et al.: p. 214, fig. 163, 4 c, d (holotype).

1997 Pseudothurmannia balearis (Nolan); Vašíček: p. 237, pl. 2, fig. 2.

2002 Balearites balearis (Nolan); Vermeulen et al.: pl. 1, fig. 3 (holotype).

non 2003 Crioceratites balearis (Nolan); Company et al.: p. 680 fig. 5.3 (= Balearites shankariae Sarkar), non fig. 5.1 (= Balearites oicasensis Hoedemaeker), non fig. 5.2 (= ?Binelliceras binelli Astier).

non 2004 Pseudothurmannia (Balearites) balearis (Nolan); Kakabadze: p. 387 , pl. 2, fig. 5 (= ?Pseudothurmannia /Kakabadziella/ ohmi valbonettensis Hoedemaeker).

non 2005 Pseudothurmannia (Balearites) balearis (Nolan); Kakabadze: p. 351, pl. 72, fig. 2 (= ?Pseudothurmannia /Kakabadziella/ valbonettensis Hoedemaeker).

2013 Crioceratites (Balearites) balearis Nolan; Hoedemaeker: p. 101, figs. $56 \mathrm{~A}, \mathrm{G}, \mathrm{I}, \mathrm{L}$ ?H, non B-F, J, K (= Balearites shankariae Sarkar), fig. 57, tab. 17.

M a te ri a I. - A sculpture mould, strongly flatly compressed (spec. SNM Z 21143) with the earliest whorls not preserved.

D e s c ription. - Whorls are in contact. The earliest poorly preserved sculpture begins at a shell diameter of $\sim 8 \mathrm{~mm}$ It consists of closely spaced, thin ribs that are near the external side inclined towards the aperture. The ribs do not visibly bear tubercles. This trend can be observed as far as a diameter of $27.5 \mathrm{~mm}$, where the first weak umbilical tubercles appear. From them, ribs almost imperceptibly stronger than the other ribs run out. In the further continuation of the whorl, two ribs run out at least partly from the umbilical tubercles. The ribs are S-shaped. Between the ribs that begin in the tubercles, there are 5-6 inserted ribs. Sporadically, some of these are shorter than the other ribs.

A change in this trend of thin and dense ribbing begins to occur at a diameter of $\sim 42 \mathrm{~mm}$. A short distance before, all ribs strengthen somewhat. From this diameter, unambiguously stronger main ribs run out from somewhat bullate umbilical tubercles of comma type. On the back side of these main ribs, a constriction is visible mainly on the external half of the whorl stretches. The inserted ribs, 10 to 12 , are not of the same length; in places they are more closely and in places more widely spaced.

Another change in sculpture formation occurs at a diameter of $\sim 54 \mathrm{~mm}$. From a comparatively noticeable non-bullate umbilical tubercle, a single main rib, accompanied on the back side by a constriction, runs out. Between the main ribs, there are 8-10 inserted ribs. Some of them bifurcate near the ventral side.
Measurement. - The maximum diameter of the specimen is $\sim 60 \mathrm{~mm}$. The measured values are a little affected by the deformation of the shell:

$$
\begin{aligned}
& \mathrm{D}_{1}=54.5 \mathrm{~mm} \mathrm{H} \mathrm{H}_{1}=19.5(0.36) \quad \mathrm{U}_{1}=21.0(0.385) \\
& \mathrm{D}_{2}=47.9 \mathrm{~mm} \mathrm{H}_{2}=17.8(0.37) \quad \mathrm{U}_{2}=17.2(0.36) \\
& \mathrm{D}_{3}=46.4 \mathrm{~mm} \mathrm{H} \mathrm{H}_{3}=17.7(0.38) \quad \mathrm{U}_{3}=16.1(0.35) \\
& \mathrm{D}_{4}=35.5 \mathrm{~mm} \mathrm{H}_{4}=15.0(0.42) \quad \mathrm{U}_{4}=11.3(0.32) \\
& \mathrm{D}_{5}=27.5 \mathrm{~mm} \mathrm{H} \mathrm{H}_{5}=12.0(0.42) \quad \mathrm{U}_{5}=8.5(0.31)
\end{aligned}
$$

At a diameter of $\sim 58 \mathrm{~mm}$, there are 6 main ribs and 58 peripheral ribs per half of the whorl. At $D=38 \mathrm{~mm}$, there are $\sim 75$ peripheral ribs per half-whorl. Egression appears at a diameter of $\sim 50 \mathrm{~mm}$.

R e m a rks. - Hoedemaeker (2013) considered Balearites shankariae Sarkar, 1955 only as a variant of $B$. balearis. As follows from our description of the following species, we regard $B$. shankariae as an individual species (as with Kakabadze, 2004, and others). Thus, the synonymy of $B$. balearis by Hoedemaeker is considerably affected. For this reason, we have tried to create modified synonymies of both these species.

We consider that one of features differentiating both species is shell size; the shell size of $B$. shankariae is smaller than that of $B$. balearis. The first comma-shaped bullate tubercles appear in $B$. shankariae at a shell diameter of $\sim 8 \mathrm{~mm}$. In $B$. shankariae, at a diameter of $\sim 15 \mathrm{~mm}$, the main ribs with umbilical tubercles begin to differ slightly from the inserted ribs. The main ribs are densely spaced. In $B$. balearis, these features appear later. Another difference is a negligible uncoiling of juvenile whorls of $B$. shankariae, where the gap between them is occupied by very short spines. On adult shells of $B$. balearis, the distinctive main ribs are accompanied by constrictions.

$\mathrm{D}$ i s t ribution. $-B$. balearis is a zonal species of the ammonite zone of the same name (lower part of Upper Hauterivian). It is known from France, Switzerland, Spain and Slovakia.

O c c u r r e n c e. - A single specimen comes from level IV the Polomec Hill Quarry, section at $40 \mathrm{~m}$, layer No. 8 (Balearis Zone).

\section{Balearites shankariae Sarkar, 1955 (Figs. 3A, 4A and 6A, B)}

1955 Balearites shankariae n. sp.; Sarkar: p. 146, pl. 11, fig. 12. ?1964 Crioceratites (Crioceratites) binelli (Astier); Thomel: p. 28 , pl. 3, fig 3, non fig. 2 (= Balearites theodomirensis Hoedemaeker).

?1967 Balearites shankariae Sarkar; Dimitrova: p. 76, pl. 36 fig. 2.

1989 Pseudothurmannia shankariae Sarkar; Vašíček: p. 118, pl. 1, fig. 5 .

1994 Pseudothurmannia shankariae (Sarkar); Vašíček et al.: p. 66 , pl. 19 , fig. 5 .

1995 Pseudothurmannia (Pseudothurmannia) shankariae (Sarkar); Vašíček: pl. 4, fig. 1.

1995 Pseudothurmannia (Balearites) shankariae Sarkar; Hoedemaeker: p. 231, pl. 3, figs. 2, 3, ?fig. 1.

2003 Crioceratites balearis (Nolan); Company et al.: p. 689, fig. 5.3, non fig. 5.1 (= Balearites oicasensis Hoedemaeker), non fig. 5.2 (= ?Binelliceras binelli Astier).

2013 Crioceratites (Balearites) balearis Nolan; Hoedemaeker: p. 101, fig. 56, B-F, J, K, non A, G, I, L, ?H (= Balearites balearis Nolan). 


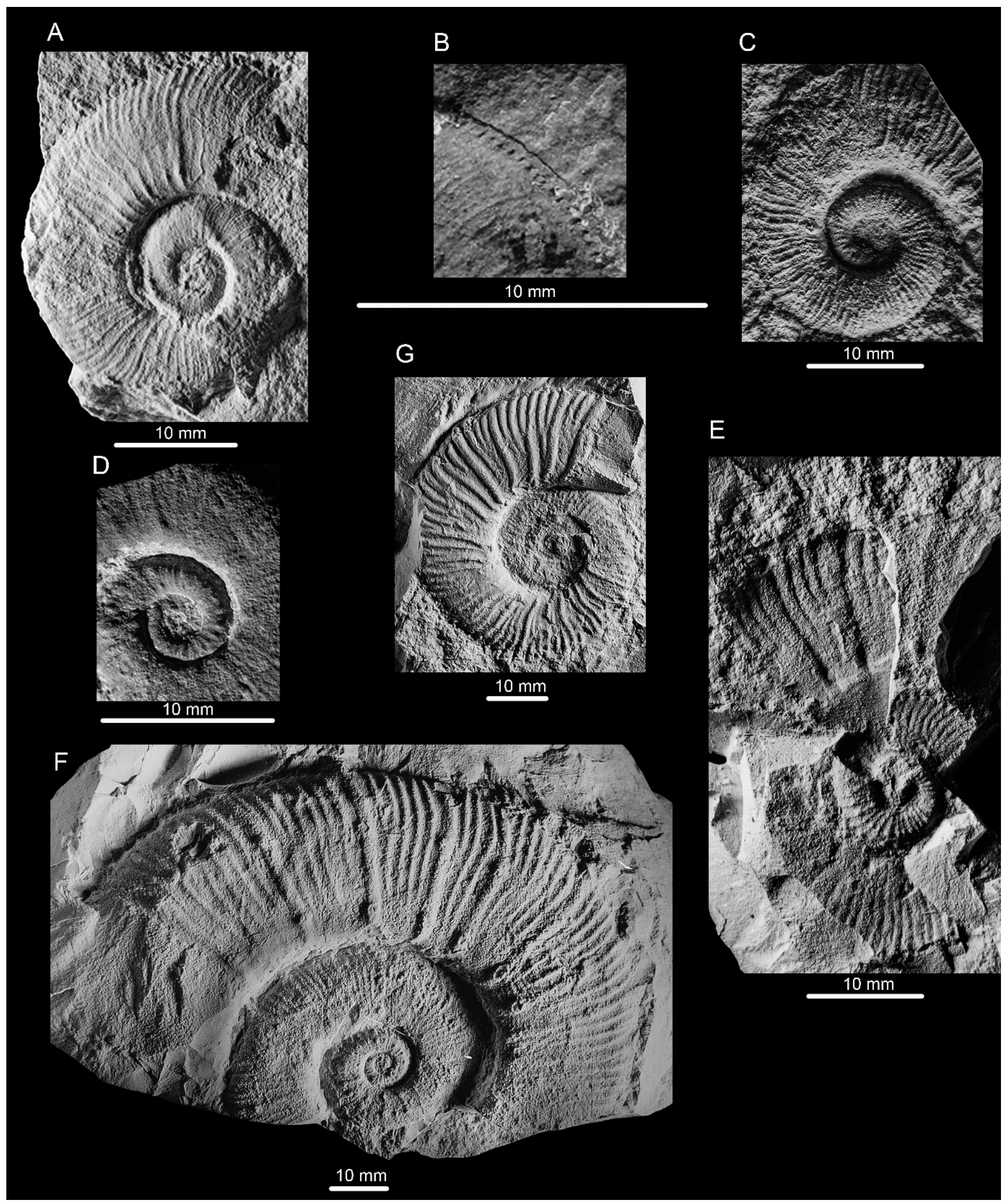

Fig. 6A - Balearites shankariae Sarkar, 1955, spec. SNM Z 21145, level IV at 40 m, debris, Balearites Zone; B - Balearites shankariae Sarkar, 1955, the same specimen as on the Figure 6A, detail of ribbing on the beginning of last whorl; C - Balearites oicasensis Hoedemaeker, 2013, spec. SNM Z 38611, level V at $250 \mathrm{~m}$, layer 5, Ohmi Zone, the photograph with the whitening without visible spines; D - Binelliceras krenkeli (Sarkar, 1955), spec. SNM Z 38613, level V at 250 m, layer 14, Ohmi Zone; E - Binellicetras rotundatus Sarkar, 1955, spec. SNM Z 21148, level V at $500 \mathrm{~m}$, layer 33, Ohmi Zone; F - Binellicetras michalíki n. sp., spec. SNM Z 38623, holotype, level V at $250 \mathrm{~m}$, Ohmi Zone; G - Pseudothurmannia ohmi ohmi (Winkler, 1868), spec. SNM Z 21149, outcrop at $260 \mathrm{~m}$ on the level V, Ohmi Zone 
$\mathrm{M}$ a t e $\mathrm{r}$ i a I. - A single sculpture mould, flatly compressed (spec. SNM Z 21145). According to the negligible remains of sutures, the phragmocone ends at a diameter of $\sim 20 \mathrm{~mm}$.

D e s c r i p t i o n. - A very slightly uncoiled specimen. The earliest, markedly unclear sculpture can be observed at a shell diameter of $\sim 4.5 \mathrm{~mm}$. Not too distinct, densely spaced, thin ribs of uniform type with weak lateral turbercles are apparent. After an interruption of ribbing at a diameter from $\sim 7.5$ to $8 \mathrm{~mm}$, comparatively long, bullate umbilical tubercles of comma type are preserved on about every fourth rib. At these, ribs may bifurcate. Between the ribs with tubercles, 3-4 (sometimes only 2) inserted ribs occur further. All ribs are very thin and very densely spaced. This trend continues as far as a diameter of 13-14 mm. Where the previous whorl is not overlain by the terminal whorl, miniature spines are preserved on all ribs on the periphery. The negligible uncoiling of the shell can be seen here as well. All ribs are slightly concave towards the mouth and S-shaped. On the lower part of the whorl, the ribs are bent only slightly. On the external half of the whorl, the ribs are markedly inclined towards the mouth.

At a diameter of $\sim 15 \mathrm{~mm}$ (on the part of the whorl preserved poorly), the main ribs begin to differ from the inserted ribs. They bear weak bullate umbilical tubercles. At a diameter of $\sim 19 \mathrm{~mm}$, usually 1-2 shorter ribs are inserted into the weaker, but still distinctive main ribs. In the case of two inserted ribs, some of these run exceptionally as far as the line of coiling. All ribs bear very small ventrolateral tubercles, and on better preserved parts they end with tiny spines. The ribs are still S-shaped. In some cases, 2 main ribs run out from the umbilical tubercle near the mouth of the specimen.

$\mathrm{M}$ e a s u r e $\mathrm{m}$ e $\mathrm{n} \mathrm{t}$. $-\mathrm{A}$ deformed specimen reaches the maximum diameter of only about $31 \mathrm{~mm}$. At $\mathrm{D}=30.9 \mathrm{~mm}, \mathrm{H}=$ $11.4 \mathrm{~mm}$ (0.37), $\mathrm{U}=11.7(0.38)$.

$\mathrm{R}$ e $\mathrm{m}$ a $\mathrm{r} \mathrm{k} \mathrm{s}$. - A brief description of the holotype in Sarkar (1955) is close to our findings. $B$. shankariae is characterized by thin and very dense ribbing, also on later whorls. The appearance of umbilical tubercles on slightly stronger ribs, that can be regarded as the beginning of the main ribs, is early. On each rib, tiny ventrolateral tubercles occur, on which there are very short spines (Fig. 6B), as already mentioned in the comparison of $B$. shankariae and $B$. balearis in remarks concerning the latter species. The assumption of Hoedemaeker (2013: p. 105) that the Slovak specimen designated as Pseudothurmannia shankariae (see synonymy) is identical with the initial whorls of Pseudothurmannia (Kakabadziella) ohmi ohmi (Winkler, 1868), does not correspond to the morphological features of the Slovak specimen and its stratigraphic position (Balearis Zone).

$D$ i s $t r$ i b u t i o n. - B. shankariae, as with B. balearis, occurs in the Balearis Zone. It is reported from France, Spain and Slovakia.

O c c u r r e n c e. - A single specimen comes from level IV in one of the quarries of Polomec Hill Quarry, debris below the section at $40 \mathrm{~m}$ (Balearis Zone).

Balearites theodomirensis Hoedemaeker, 2013 (Figs. 4B and 5B, C)

1964 Balearites sp.; Fülöp: pl. 16, fig. 6, non pl. 9, fig. 7 (= ?Pseudothurmannia (Kakabadziella) caravacensis Hoedemaeker).

1964 Crioceratites (Crioceratites) binelli (Astier); Thomel: p. 28, pl. 3, fig. 2, non fig. 3 (= Balearites shankariae Sarkar).
2013 Crioceratites (Balearites) theodomirensis sp. nov.; Hoedemaeker: p. 105, fig. 58, pl. 36, figs. 1-17, tab. 18 (cum syn.).

$\mathrm{M}$ a t e ri a l. - Six not too large specimens that belong to the category of microconchs, preserved as sculpture moulds (specs. SNM Z 38605, 38607-10) and further, one rather large specimen deformed slightly by lateral pressure (spec. SNM Z 38606) that belongs to macroconchs.

$\mathrm{Mi}$ c r o c o n ch de s cription. - Evolute to negligibly uncoiled specimens. The flanks of narrow whorls are flat, slope gradually from the umbilicus to the narrow ventral side. The specimens reach $\sim 40 \mathrm{~mm}$. On spec. SNM Z 38608 the body chamber begins at a diameter of $29 \mathrm{~mm}$.

The first remains of the sculpture are apparent at a diameter of $\sim 5 \mathrm{~mm}$, where the periphery of the whorl is imperfectly preserved. Ribs of that place are comparatively widely spaced, simple with quite evident longitudinally elongated lateral tubercles. At a diameter of $\sim 6 \mathrm{~mm}$, the ribs are thinner and notably denser. They bear weak lateral tubercles. In some places, very weak umbilical tubercles are developed as well. Between these ribs, two and later up to 4 ribs are inserted. All ribs bear tiny lateral tubercles. At a diameter of $\sim 12 \mathrm{~mm}$ the lateral tubercles disappear. At a diameter of $13 \mathrm{~mm}$, the main ribs begin to differentiate. They begin in comparatively distinctive bullate umbilical tubercles. Between the main ribs, which may bifurcate in the umbilical tubercles, 3-4 inserted ribs occur. The inserted ribs have different lengths; the majority of them do not reach the line of coiling. On the ventral side, all ribs bear quite distinctive conical ventrolateral tubercles. At a specimen diameter of $\sim 20 \mathrm{~mm}$, the ribs strengthen and the ribs with umbilical tubercles become more densely spaced. Between the pairs of ribs with umbilical tubercles, two inserted ribs usually occur. The main ribs may bifurcate at about a half of the whorl height. At the ends of the microconchs, there are weak constrictions before the main ribs. The number of inserted ribs varies from 2 to 5 .

$\mathrm{M}$ e a s u re m e $\mathrm{nt}$. - The maximum diameter of specimen SNM Z 38605 is $~ 35 \mathrm{~mm}$. At measured diameters:

$$
\begin{aligned}
& \mathrm{D}_{1}=34.5 \mathrm{~mm} \mathrm{H} \mathrm{H}_{1}=12.6(0.365) \quad \mathrm{U}_{1}=12.8(0.37) \\
& \mathrm{D}_{2}=31.6 \mathrm{~mm} \mathrm{H} \mathrm{H}_{2}=11.4(0.36) \quad \mathrm{U}_{2}=11.7(0.37) \\
& \mathrm{D}_{3}=30.0 \mathrm{~mm} \mathrm{H} \mathrm{H}_{3}=11.0(0.37) \quad \mathrm{U}_{3}=10.8(0.36) \\
& \mathrm{D}_{4}=25.2 \mathrm{~mm} \mathrm{H}_{4}=10.2(0.40) \quad \mathrm{U}_{4}=9.1(0.36) \\
& \mathrm{D}_{5}=20.0 \mathrm{~mm} \mathrm{H}=8.2(0.41) \quad \mathrm{U}_{5}=6.9(0.345) \\
& \text { - measured along the same ray with } D_{2} \text {. }
\end{aligned}
$$

At a specimen diameter of $30 \mathrm{~mm}$, there are 42 peripheral ribs per half-whorl. The main ribs are innumerable. Egression appears at a diameter of $\sim 33 \mathrm{~mm}$.

The specimen SNM Z 38607 has a diameter of $36.5 \mathrm{~mm}$. The measured parameters are somewhat affected by slight deformation:

$$
\begin{array}{ll}
\mathrm{D}_{1}=36.5 \mathrm{~mm} \mathrm{H} \mathrm{H}_{1}=14.0(0.38) & \mathrm{U}_{1}=12.7(0.35) \\
\mathrm{D}_{2}=28.5 \mathrm{~mm} \mathrm{H} \mathrm{H}_{2}=12.0(0.42) & U_{2}=9.5(0.33)
\end{array}
$$

Per half-whorl there are about 12 main ribs and 52 ribs on the periphery at a diameter of $36.5 \mathrm{~mm}$.

The specimen SNM Z 38610 has a maximum diameter of $39.5 \mathrm{~mm}$ :

$$
\begin{array}{lll}
\mathrm{D}_{1}=38.5 \mathrm{~mm} \quad \mathrm{H}_{1}=13.6(0.35) & \mathrm{U}_{1}=15.7(0.41) \\
\mathrm{D}_{2}=33.6 \mathrm{~mm} \mathrm{H} \mathrm{H}_{2}=12.4(0.37) & U_{2}=12.7(0.38) \\
\mathrm{D}_{3}=28.6 \mathrm{~mm} \mathrm{H}_{3}=11.2(0.39) & \mathrm{U}_{3}=10.8(0.38) \\
\mathrm{D}_{4}=27.2 \mathrm{~mm} \mathrm{H} \mathrm{H}_{4}=11.0(0.40) & U_{4}=10.1(0.37)
\end{array}
$$

At a diameter of $38.5 \mathrm{~mm}$, there are $\sim 10$ main ribs and 44 peripheral ribs per half-whorl.

Macroconch description. - The sculpture is more favourably preserved from a diameter of $27 \mathrm{~mm}$. The specimen (SNM Z 38606) is affected by slight lateral deformation, in addition to flat compression. A negligibly uncoiled speci- 
men or shells with whorls in contact. The earliest sculpture is imperfectly preserved on a short part at a diameter of $\sim 11 \mathrm{~mm}$. Weak main ribs with indicated umbilical tubercles and maybe also with weak lateral tubercles are poorly visible there. Between the main ribs, $\sim 3$ thin ribs are inserted. After an interruption of the sculpture, on about one quarter of the whorl, a rather strong main rib with a weak umbilical tubercle and poorly preserved 2-3 inserted ribs can be seen at D of $\sim 14.5 \mathrm{~mm}$. In the further continuation of the whorl, rather widely spaced conical umbilical tubercles are apparent merely at the umbilicus. Between them, $\sim 3$ ribs may be inserted.

At $D$ of $\sim 23 \mathrm{~mm}$, thin main ribs beginning with small umbilical tubercles are visible. Between them, 2-3 thin ribs of different lengths are inserted. The middle rib (in the case of 3 ribs) almost reaches the line of coiling. The ribs are S-shaped.

The better preserved sculpture begins at the beginning of the last whorl at a diameter of $\sim 27 \mathrm{~mm}$. The ribs are clearly S-shaped. The main, still somewhat thin and weak ribs begin with bullate umbilical tubercles. Lateral tubercles are not apparent. The main ribs end with weak ventrolateral tubercles. Before the main ribs, there are narrow, weak constrictions. Between the main ribs, 4 to 5 ribs are inserted. They disappear below half the whorl height. At least some of these bear small ventrolateral tubercles.

At a diameter of $38 \mathrm{~mm}$, the phragmocone and relatively thin ribbing end. On the body chamber, ribs are markedly stronger. The main S-shaped ribs begin with distinct, shortly bullate umbilical tubercles. They end in ventrolateral tubercles. Between them, 3-4 ribs are inserted; there are ventrolateral tubercles, weaker than those on the main ribs, on them. There are constrictions before the main ribs.

After the incomplete quarter of the whorl at the end of the shell, ribbing is preserved unclearly, maybe affected by corrosion, especially on the bottom half of the whorl height. Constrictions before the main ribs are significantly distinct on the peripheral part of the shell. Between the main ribs, 5-7 shorter ribs are inserted.

$\mathrm{M}$ e a s u re m e $\mathrm{nt}$. - The deformed macroconch (spec. SNM Z 38606) reaches the maximum diameter of $\sim 61 \mathrm{~mm}$ :

$$
\begin{array}{ll}
\mathrm{D}_{1}=60.2 \mathrm{~mm} \mathrm{H} \mathrm{H}_{1}=21.0(0.35) & U_{1}=24.5(0.41) \\
\mathrm{D}_{2}=56.0 \mathrm{~mm} \mathrm{H} \mathrm{H}_{2}=20.3(0.36) & U_{2}=21.6(0.385) \\
\text { - in the axis of elongation, } & \\
\mathrm{D}_{3}=52.0 \mathrm{~mm} \mathrm{H} \mathrm{H}_{3}=19.5(0.375) & \mathrm{U}_{3}=20.8(0.40) \\
- \text { between the axes of deformation, } \\
\mathrm{D}_{4}=41.5 \mathrm{~mm} \mathrm{H} \mathrm{H}_{4}=16.3(0.39) \quad \mathrm{U}_{4}=16.4(0.395) \\
\mathrm{D}_{5}=39.0 \mathrm{~mm} \mathrm{H} \mathrm{H}_{5}=14.5(0.37) \quad \mathrm{U}_{5}=15.0(0.38) \\
\text { - measured along the same ray with } \mathrm{D}_{1}, \\
\mathrm{D}_{6}=35.4 \mathrm{~mm} \mathrm{H}_{6}=14.3(0.40) & \mathrm{U}_{6}=13.0(0.37) \\
\text { - measured on the same ray with } \mathrm{D}_{2} .
\end{array}
$$

At a diameter of $60.2 \mathrm{~mm}$ there are 11 main ribs (peripheral ribs are not preserved) per half-whorl, at a diameter of $39 \mathrm{~mm}$ there are 10 main ribs and $\sim 54$ peripheral ribs per half-whorl. Egression appears at a diameter of $\sim 42 \mathrm{~mm}$.

$\mathrm{R}$ e $\mathrm{m}$ a r k s. - From the stratigraphically older representatives of the genus Balearites with the short-lasting trituberculate juvenile stage, $B$. theodomirensis differs by the longer trituberculate stage up to a diameter of almost $12 \mathrm{~mm}$. It is probable that smaller specimens reaching a diameter of $\sim 40 \mathrm{~mm}$, with the end of the phragmocone at a diameter of $\sim 25 \mathrm{~mm}$, belong to microconchs. Larger specimens with a diameter of $\sim 60 \mathrm{~mm}$, on the body chambers of which stronger main ribs accompanied by constrictions occur, belong to macroconchs (see also Hoedemaeker's specimens, 2013, in pl. 36, figs. 3, 16, 17).
Juvenile whorls of microconchs have the value of $H / D$ greater than that of $U / D$. At a shell diameter of $33 \mathrm{~mm}$, egression appears when at larger diameters of shells, H/D is smaller than U/D. On macroconchs, egress occurs at a diameter $>40 \mathrm{~mm}$ (see also Hoedemaeker, 2013, tab. 18).

D i s t r i b u t i o n. - According to Hoedemaeker (2013) in the section at Río Argos A, B. theodomirensis occurs not until the Ohmi ammonite Zone, whereas in the section W it appears in the higher part of the Balearis Zone. The species is known from France, Spain, Hungary and Slovakia.

O c curre n c e. - In the Na piate Quarry on Polomec Hill, $B$. theodomirensis occurs only at level $\mathrm{V}$ in the lower part of the section at $250 \mathrm{~m}$ (LL V-250).

\section{Balearites oicasensis Hoedemaeker, 2013 (Figs. 3B, 4C, 5D, E and 6C)}

1994 Pseudothurmannia balearis (Nolan); Vašíček et al.: p. 66, pl. 19, fig. 4 , non fig. 3 (= Crioceratites (Balearites) balearis Nolan).

1995 Pseudothurmannia (Balearites) balearis (Nolan); Vašíček: p. 174, pl. 4, fig. 5.

2002 ?Pseudothurmannia "binelli" Thomel, 1964, non Astier, 1851; Vašíček: p. 194, pl. 2, fig. 7, non fig. 6 (= Binelliceras rotundatus Hoedemaeker).

2003 Crioceratites balearis (Nolan); Company et al.: p. 689, fig. 5.1, non fig. 5.2 (= ?Binelliceras binelli Astier), non fig. 5.3 (= Balearites shankariae Sarkar).

2013 Crioceratites (Balearites) oicasensis nov. sp.; Hoedemaeker: p. 108, fig. 60 A-C, tab. 20.

M a t e ri a I. - A juvenile specimen SNM Z 38611 preserved as a limonitised internal mould and two sculpture moulds, i.e. a smaller specimen (SNM Z 38612) and an adult specimen (SNM Z 21144). The latter specimen is dissected by a filled fissure, which is connected with strong deformation of the final half of the shell. Its phragmocone ends at a diameter of $34 \mathrm{~mm}$.

D e s c ription. - Juvenile specimens with slightly uncoiled whorls. The earliest sculpture is apparent at a diameter of $\sim 4.5 \mathrm{~mm}$. It consists of moderately strong, rather blunt, comparatively closely spaced, simple ribs, at the very beginning with stronger, and further with somewhat weaker, longitudinally elongated lateral tubercles. The lateral tubercles are there on all ribs. The ribs are probably trituberculate. Umbilical tubercles are not, with regard to specimen preservation, apparent. At a diameter of $\sim 7 \mathrm{~mm}$, the lateral tubercles begin to weaken. All ribs bear tiny ventrolateral tubercles on which there are very short spines (Fig. 3B). The last lateral tubercle is apparent at a diameter of $9.5 \mathrm{~mm}$. Several poorly preserved probably uniform ribs follow.

At a diameter of $\sim 15 \mathrm{~mm}$, the first conical umbilical tubercle is apparent. From some umbilical tubercles, two ribs run out. All ribs are equally strong. Between the ribs with umbilical tubercles, 4 ribs are inserted. The ribs are S-shaped. Some inserted ribs are shorter than the other ribs. Thin, dense ribbing ends at a diameter of $\sim 21 \mathrm{~mm}$. From a diameter of $27.5 \mathrm{~mm}$, stronger ribs of comma type run out from umbilical tubercles. They take the character of the main ribs. From them, a weaker rib splits on their back side in the lower third of the whorl. On the periphery of the main ribs, a ventrolateral tubercle is usually apparent. Before the main ribs, there are weak and narrow constrictions that 
become gradually stronger. Between the main ribs, $7-8$ ribs are usually inserted. They bear tiny ventrolateral tubercles. On the body chamber, the number of ribs inserted between the umbilical tubercles usually reduces to a half. At the end of spec. 21144 , pairs of prominent ribs, accompanied along the front side by a wide and shallow constriction, occur from a diameter of $\sim 56 \mathrm{~mm}$.

M e a s u r e m e $n$ t. - Specimen SNM Z 38612 reaches a diameter of $42.5 \mathrm{~mm}$ :

$$
\begin{array}{lll}
\mathrm{D}_{1}=40.0 \mathrm{~mm} \mathrm{H} & \mathrm{H}_{1}=14.6(0.365) & \mathrm{U}_{1}=15.0(0.375) \\
\mathrm{D}_{2}=31.5 \mathrm{~mm} \mathrm{H} \quad \mathrm{H}_{2}=12.5(0.40) & U_{2}=12.2(0.39) \\
\mathrm{D}_{3}=28.0 \mathrm{~mm} \mathrm{H} \mathrm{H}_{3}=11.0(0.39) & U_{3}=9.8(0.35)
\end{array}
$$

Per half-whorl, there are 12 main ribs and $\sim 54$ peripheral ribs at a diameter of $40 \mathrm{~mm}$.

Specimen SNM Z 21144 reaches the maximum diameter of $\sim 61 \mathrm{~mm}$. The measurement is affected by fissure damage on the specimen:

$$
\begin{array}{lll}
\mathrm{D}_{1}=58.0 \mathrm{~mm} \quad \mathrm{H}_{1}=22.2(0.38) & U_{1}=20.3(0.35) \\
\mathrm{D}_{2}=32.0 \mathrm{~mm} \quad \mathrm{H}_{2}=12.9(0.40) & U_{2}=11.0(0.37) \\
\text { - measured on the same ray as with } \mathrm{D}_{1}, \\
\mathrm{D}_{3}=29.7 \mathrm{~mm} \quad \mathrm{H}_{3}=11.6(0.39) & U_{3}=10.0(0.34) .
\end{array}
$$

Remarks. - Balearites oicasensis differs from $B$. balearis by earlier appearance of the main ribs and constrictions. The inner whorls of Binelliceras rotundatus Sarkar, which in some degree are reminiscent of $B$. oicasensis, have the main ribs stronger and the number of inserted ribs is smaller than in $B$. oicasensis.

D i s t r i b u t i o n. - According to Hoedemaeker (2013), $B$. oicasensis occurs in the Balearis Zone in Spain and in Slovakia.

O c c u r r e n c e. - Na piate Quarry on Polomec Hill, in the higher parts of both ammonite-bearing sections. The species is also known from the Klippen Belt in the locality of Podbranč (Vašíček, 2002)

Genus Binelliceras Sarkar, 1977

T y p e s p e c i e s. - Ancyloceras Binelli Astier, 1851

$\mathrm{R}$ e $\mathrm{m}$ a r k s. - Whorls are slightly crioconic. The earliest whorls bear lateral tubercles up to a diameter ranging from 11 to $23 \mathrm{~mm}$. On inner whorls, there are ventrolateral tubercles; in some species they continue as far as the mouth of adult shells. On early whorls, fibulation occurs frequently. On later whorls there are usually strong main ribs that are accompanied by a rather small number of weaker and usually shorter inserted ribs. Hoedemaeker (2013: p. 110) divides Binelliceras into two groups: Binelli and Angulicostatus.

\section{Binelli Group}

$\mathrm{R}$ e $\mathrm{m}$ a r k s. - Trituberculate ribs of the earliest part occur at the shell diameter of $11-17 \mathrm{~mm}$. Continuation is characterised by a long stage of thin uniform flexuous ribs as far as a diameter ranging from 25 to $50 \mathrm{~mm}$. More differentiated ribbing follows. The adult part is characterized by main ribs with umbilical bullae, or irregular distribution or irregular curvature of main ribs and inserted ribs. The main ribs are separated by a rather small number of weaker, usually shorter inserted ribs.
Binelliceras krenkeli (Sarkar, 1955)

(Figs. 4D, 5F and 6D)

1894 Crioceras Picteti var. majoricensis nobis; Nolan: p. 186, pl. 10 , fig. $1 d$,

non fig. 1a, b (= Crioceratites majoricensis Nolan), non fig. 1c (= Binelliceras binelli Astier).

1955 Crioceras krenkeli n. sp.; Sarkar: p. 37, pl. 5, fig. 5, text-fig. 4C.

?1964 Crioceratites (Crioceratites) krenkeli (Sarkar); Thomel: p. 23, pl. 2, figs. 2, 3 .

1983 Crioceratites (Crioceratites) quenstedti (Ooster); Adamíková et al.: p. 604, pl. 1, fig. 2.

2013 Crioceratites (Binelliceras) krenkeli Sarkar; Hoedemaeker: p. 112, fig. $62 \mathrm{~A}-\mathrm{F}$, tab. 22 (cum syn.).

$\mathrm{M}$ a t e ri a I. - Four rather larger specimens, comparatively favourably preserved as sculpture moulds (specs. SNM Z $21147,38615-17$ ) and several other specimens preserved less favourably. None of these specimens reaching rather large diameters has an apparent sculpture of early whorls. Furthermore, one juvenile specimen SNM Z 38613

D e s c r i p t i o n. - Slightly or unclearly coiled specimens with slightly vaulted whorls. On specimens with juvenile whorls that are best preserved, the sculpture begins to be apparent at diameters from 4.5 to $7 \mathrm{~mm}$. If the whorl is exceptionally apparent even before the stated minimum diameter of the shell, it seems to be smooth. Initial ribbing is formed by widely spaced, rather strong simple ribs. All bear a visible lateral tubercle. Within a short distance, some ribs as well as lateral tubercles gradually weaken. In some specimens, small ventrolateral tubercles are apparent on all ribs as well. At a diameter of $\sim 7 \mathrm{~mm}$, the first umbilical tubercle is preserved. Between the ribs with umbilical tubercles, there are from one to two ribs without tubercles inserted from the beginning. Ribs bearing umbilical tubercles gradually strengthen in comparison with the other ribs. Lateral tubercles are stronger on these than on the other ribs. At a diameter of $\sim 11 \mathrm{~mm}$, where the ribs are still thin and dense, two ribs usually run out from weak umbilical tubercles. Between the pairs of umbilical tubercles, 5 ribs without these tubercles occur. As far as the diameter of almost $18 \mathrm{~mm}$, tiny lateral tubercles are still apparent on all ribs.

From a diameter of $18 \mathrm{~mm}$ to that of $32 \mathrm{~mm}$, sculpture is formed by uniform, thin, quite dense, S-shaped ribs. In the umbilical area, clear, slightly bullate umbilical tubercles, from which simple ribs or pairs of ribs run out, appear. The pairs of ribs in places join in a ventrolateral clavate tubercle (fibulation). Between umbilical tubercles, there is a variable, usually rather high number (sometimes even 6,7 ) of inserted ribs. They usually have various lengths; some bifurcate. Inserted ribs usually do not reach the line of coiling. On some specimens, small clavate ventrolateral tubercles are preserved on all ribs in the given part. It seems that, in some cases, the fibulation becomes evident here. In a particularly favourable case of preservation, numerous, up to $1 \mathrm{~mm}$ long spines running from the ventrolateral tubercles are locally preserved in the gap between the whorls. These tubercles are rather more robust and clavate on ribs with the character of main ribs.

From a diameter of $\sim 32 \mathrm{~mm}$, the main ribs begin to be differentiated from previously equal ribs, which is evident especially in the periumbilical area. Umbilical tubercles strengthen. Clavate ventrolateral tubercles become more robust on the main ribs then they were before. Ribs still bifurcate in the umbilical tubercles. 
At a diameter of $40 \mathrm{~mm}$ and more, the main ribs are more distinct along their whole length. In the end part of the shell, the main ribs are usually accompanied by weak constrictions. The main ribs begin in umbilical tubercles, in which they locally bifurcate; they end in clavate ventrolateral tubercles. Between the main ribs, there are usually $4-6$ inserted ribs. Some of these reach as far as the umbilicus, others are shorter.

$\mathrm{M}$ e a s u re me $\mathrm{nt}$. - The best preserved adult specimens have diameters of $50-55 \mathrm{~mm}$.

Spec. 38614 (Dmax $=52.7 \mathrm{~mm})$ :

$\begin{array}{ll}\mathrm{D}_{1}=50.7 \mathrm{~mm} \mathrm{H}_{1}=19.0(0.37) & U_{1}=20.0(0.39) \\ \mathrm{D}_{2}=35.9 \mathrm{~mm} \mathrm{H}_{2}=14.4(0.40) & U_{2}=12.9(0.36) \\ \mathrm{D}_{3}=20.0 \mathrm{~mm} \mathrm{H}_{3}=7.9(0.395) & U_{3}=7.0(0.35)\end{array}$

$\mathrm{D}_{4}=11.4 \mathrm{~mm} \mathrm{H}_{4}=4.4(0.385) \quad \mathrm{U}_{4}=3.6(0.32)$

On the final half-whorl, there are 9 main ribs and 50 peripheral ribs.

Specimen SNM Z 38615:

$\mathrm{D}_{1}=53.2 \mathrm{~mm} \mathrm{H} \mathrm{H}_{1}=19.3(0.36) \quad \mathrm{U}_{1}=20.4(0.38)$

$\mathrm{D}_{2}=45.0 \mathrm{~mm} \mathrm{H}_{2}=17.2(0.38) \quad \mathrm{U}_{2}=17.0(0.38)$

$\mathrm{D}_{3}=41.3 \mathrm{~mm} \mathrm{H}_{3}=17.0(0.41) \quad \mathrm{U}_{3}=15.2(0.37)$

$\mathrm{D}_{4}=34.9 \mathrm{~mm} \mathrm{H} \mathrm{H}_{4}=14.0(0.40) \quad \mathrm{U}_{4}=12.4(0.355)$

$\mathrm{D}_{5}=26.8 \mathrm{~mm} \mathrm{H}_{5}=11.6(0.43) \quad \mathrm{U}_{5}=9.0(0.37)$

$\mathrm{D}_{6}=20.4 \mathrm{~mm} \mathrm{H}_{6}=8.6(0.42) \quad \mathrm{U}_{6}=7.0(0.34)$

At Dmax, there are 9 main ribs and 48 peripheral ribs per half-whorl. Egression in this specimen appears at a diameter of $\sim 45 \mathrm{~mm}$.

On the juvenile specimen SNM Z 38613 at $D=18.7 \mathrm{~mm}$ is $\mathrm{H}=7.7$ (0.41), $\mathrm{U}=6.6$ (0.35).

$\mathrm{R}$ e $\mathrm{m}$ a r k s. - Trituberculate ribs occur on juvenile whorls up to a diameter of $\sim 18 \mathrm{~mm}$. Bin. krenkeli is reminiscent of the coarsely ribbed variant Binelliceras binelli (Astier, 1851). On more adult whorls, there are distinct clavi on the main ribs. Both species differ in stratigraphic position, where $B$. binelli occurs in the Balearis Zone, and the other in the Ohmi Zone. Bin. rotundatus Sarkar differs from $B$. krenkeli by having a considerably shorter finely ribbed stage and substantially stronger ribbing, including clear main ribs and ventrolateral spines on the main ribs.

D i s t r i b u t i o n. - B. krenkeli occurs in the lower part of the Ohmi Zone in France, Spain, Switzerland and in Slovakia.

O c currence. - Na piate Quarry on Polomec Hill, namely in the higher parts of both partial sections at 250 and $500 \mathrm{~m}$.

\section{Binelliceras ibizensis (Wiedmann, 1962)} (Figs. 4E and 5G, H)

1894 Crioceras angulicostatum d'Orbigny; Nolan: p. 195, pl. 10, fig. 3a, non fig. 3b (Crioceratites /Balearites/ rotundatus Sarkar), non fig. 3c (= Crioceratites remanei Wiedmann).

1962 Crioceratites (Pseudothurmannia) balearis ibizensis $\mathrm{n}$. ssp.; Wiedmann: p. 130.

2009 Binelliceras ibizense (Wiedmann); Vašíček et al.: p. 136, fig. 1.4.

2013 Crioceratites (Binelliceras) ibizensis (Wiedmann); Hoedemaeker: p. 114, fig. 63A-G, fig. 64A-C, pl. 38, figs. 1-14, tab. 23 (cum syn.).

$\mathrm{M}$ a t e $\mathrm{r}$ i a I. - Two flatly and laterally deformed sculptural moulds (SNM Z 38619 and 38620), coated with a limonite layer, with a slightly corroded sculpture, coming from marly limestone. The corrosion affects more significantly the juvenile whorls.

D e s c r i p t i o n. - Negligibly uncoiled specimens. The earliest sculpture is apparent at a diameter of $\sim 5 \mathrm{~mm}$. It consists of simple, rather widely spaced ribs convexly bent towards the aperture. The umbilical and ventral areas are not favourably preserved, and thus merely rather weak, somewhat longitudinally elongated lateral tubercles are preserved on the ribs. At a diameter of $\sim 8 \mathrm{~mm}$, ribbing is somewhat denser than before. Here, weak bullate umbilical tubercles, from which two ribs may run out, are visible. On all ribs, small, negligibly longitudinally elongated lateral tubercles occur. The last lateral tubercle in the continuous row disappears at a diameter of $\sim 9 \mathrm{~mm}$. After a short part with unpreserved sculpture, at a shell diameter of $\sim 12 \mathrm{~mm}$, ribs take an S-shape. In addition to the pair of ribs running out from comparatively prominent umbilical tubercles, one inserted rib running as far as the line of coiling appears between them. All ribs end with small ventrolateral tubercles. Over the ventral side, the weakened ribs run between the tubercles. This continues up to a diameter of $\sim 15 \mathrm{~mm}$. From this diameter, usually two, sometimes only one rib runs from umbilical tubercles. One of them can be slightly stronger. Sporadically, it seems that on some ribs, there are very weak lateral tubercles as well. In the space between the ribs with tubercles, from one to two inserted ribs can be found. Where only one rib is developed (which prevails), the rib is short and disappears at about half the whorl height. All ribs bear ventrolateral tubercles; the tubercles on inserted ribs are usually negligibly weaker. The ribs run across the ventral side without weakening. Up to a diameter of $\sim 21 \mathrm{~mm}$, a comparatively thin and dense ribbing persists. From a diameter of $21.5 \mathrm{~mm}$, the inserted ribs become longer and reach almost the lower quarter of the whorl. The main ribs, which are somewhat stronger than the inserted ribs, run out from one of the bullate tubercles of comma type. The ribs are strongly S-shaped. In the final part of the juvenile specimen, the main ribs alternate with the inserted ribs. This happens with only one exception. The ribs are more widely spaced and more robust than the previous ones. The inserted ribs do not reach the umbilicus.

A trend of roughly the same, comparatively thin and closely spaced S-shaped ribs, between which 2-4 ribs of usually not the same length are inserted, continues up to a diameter of $\sim 45 \mathrm{~mm}$. On the final third of the final whorl of the largest specimen 38619 (which belongs to the body chamber), ribbing is stronger and more irregular. The main ribs differ in strength from the inserted ribs. Ribs do not bifurcate in umbilical tubercles. Between the main ribs, 2-3 inserted ribs occur, usually of different lengths with a tendency towards bifurcation. Ventrolateral tubercles on the main ribs are somewhat more robust than on the inserted ones; they are slightly clavate.

M e a s u r e m e $n$ t. - Specimen SNM Z 38620 reaches the maximum diameter of $\sim 48 \mathrm{~mm}$ :

$$
\begin{array}{ll}
\mathrm{D}_{1}=44.4 \mathrm{~mm} \mathrm{H} \mathrm{H}_{1}=15.8(0.355) & \mathrm{U}_{1}=17.2(0.39) \\
\mathrm{D}_{2}=41.0 \mathrm{~mm} \mathrm{H} \mathrm{H}_{2}=15.2(0.37) & \mathrm{U}_{2}=15.6(0.38)
\end{array}
$$

The deformed specimen SNM Z 38619 reaches the maximum diameter of $\sim 64 \mathrm{~mm}$ :

$$
\begin{array}{ll}
\mathrm{D}_{1}=54.0 \mathrm{~mm} \mathrm{H} \mathrm{H}_{1}=19.6(0.36) & \mathrm{U}_{1}=21.0(0.39) \\
\mathrm{D}_{2}=51.4 \mathrm{~mm} \mathrm{H} \mathrm{H}_{2}=19.0(0.37) & \mathrm{U}_{2}=20.2(0.39) \\
\mathrm{D}_{3}=49.5 \mathrm{~mm} \mathrm{H} \mathrm{H}_{3}=18.4(0.37) & \mathrm{U}_{3}=19.0(0.38)
\end{array}
$$

At Dmax, there are 15 primary ribs and 47 peripheral ribs per half-whorl.

Remarks. - According to Hoedemaeker (2013), $B$. ibizensis is a species that varies considerably in a number of features. B. ibizensis differs from Pseudothurmannia (Kakabadziella) mortilleti (Pictet et Loriol, 1858) by the fact that whorls of the latter species are in contact, the umbilicus is wider and lateral tubercles are present on the juvenile whorl. From Balearites theodomirensis, which occurs together with $B$. ibizensis, it differs by whorls not being in contact and fibulation in $B$. ibizensis. Ventrolateral tubercles of $B$. ibizensis continue on each rib as far as the mouth. 
D is t ri b u ti o n. - According to Hoedemaeker (2013), B. ibizensis occurs in the Balearis and Ohmi Zones in Spain, France, Austria, Serbia and Slovakia.

O c c u r r e n c e. - Na piate Quarry on Polomec Hill, near the base of the section at $250 \mathrm{~m}$. B. ibizensis also occurs in the locality of Podbranč (Klippen Belt).

\section{Binelliceras rotundatus Sarkar, 1955}

(Figs. 3C, 4F and 6E)

1894 Crioceras angulicostatum d'Orbigny; Nolan: p. 195, pl. 10, fig. 3b, non fig. 3a (=Crioceratites /Binelliceras/ibizensis Wiedmann), non fig. 3c (= Crioceratites remanei Wiedmann). 1919 Crioceras Quenstedti Ooster; Rodighiero: p. 113, pl. 12, fig. 2.

1955 Pseudothurmannia mortilleti Pictet and Loriol var. rotundata nov.; Sarkar: p. 156, pl. 6, fig. 12.

2013 Crioceratites (Binelliceras) rotundatus Sarkar; Hoedemaeker: p. 117, pl. 39, figs. 1-13, pl. 40, figs. 1-7, tab. 24 (cum syn.).

$\mathrm{M}$ a t e $\mathrm{r}$ i a l. - Three incomplete juvenile specimens (SNM Z 21148, 38621, 38622)

De s c ription. - Slightly uncoiled specimens with a vaulted first juvenile whorl. The largest breadth of whorl occurs in the vicinity of the umbilicus. From there, the flanks of the whorl moderately decline to the probably narrow ventre.

The earliest sculpture is apparent at a diameter of $5.5 \mathrm{~mm}$. Here, there are moderately strong, probably trituberculate ribs. Only the lateral tubercles are preserved. From a diameter of $\sim 7 \mathrm{~mm}$, somewhat stronger ribs continue; 1 to 2 (in places even 3) weaker ribs are inserted. The stronger ribs have more distinct lateral tubercles than do the weaker ribs and in addition, they bear weak umbilical tubercles. The other part of the whorl is very unfavourably preserved. After that part, the number of inserted ribs may gradually increase to 4 up to 5 ; they reach as far as the line of coiling. At least some of them bear weak, longitudinally elongated lateral tubercles. At a diameter of $\sim 14.5 \mathrm{~mm}$, the last lateral tubercle can be seen on the main rib. From a diameter of shell $\sim 16 \mathrm{~mm}$, two ribs may run out from umbilical tubercles. In some parts of early whorls, bases of short ventrolateral spines are apparent.

On the final half-whorl (beginning at a diameter of $\sim 26 \mathrm{~mm}$ ), there are comparatively thin, subtly S-shaped ribs, between which only slightly stronger main ribs are inserted. The main ribs bear long bullate umbilical tubercles that do not bear lateral tubercles, and end with clavate ventrolateral tubercles. In some cases, the main ribs bifurcate at about half the whorl height, in other cases, two ribs run out from the umbilical tubercle or from its vicinity. In the ventrolateral tubercles, which are quite noticeable, fibulation locally occurs. Between the main ribs, there are 5-7 inserted ribs. They are usually of different length; with increasing growth they gradually disappear without reaching the line of coiling. Some inserted ribs bifurcate in the vicinity of the ventre. The main ribs end in ventrolateral spines.

Size parameters at the maximum diameter of both incomplete shells are not measurable. Specimen 38621 is estimated to reach a diameter of $\sim 40 \mathrm{~mm}$, the other of $\sim 32 \mathrm{~mm}$.

On the smaller specimen (spec. SNM Z 38622), at a diameter $\mathrm{D}=24.7 \mathrm{~mm}, \mathrm{H}=10.2(0.41), \mathrm{U}=8.9$ (0.36). No complete half-whorl necessary for determination of the number of ribs is available.
$\mathrm{R}$ e $\mathrm{m}$ a r k s. - Binelliceras rotundatus is somewhat reminiscent of $P$. (Kakabadziella) ohmi ohmi (Winkler, 1868). It differs from it by lateral tubercles on early whorls, in the shape of ventrolateral tubercles on the main ribs that are notably larger than the ventrolateral clavi of Kakabadziella ohmi ohmi, and in the common fibulation of the ribs on the inner whorls. Binelliceras krenkeli differs from $B$. rotundatus by the earlier disappearance of the lateral tubercles (at $D$ of $\sim 14 \mathrm{~mm}$ ), by a shorter part with thin uniform ribs and by more robust main ribs.

D i s t r i b u t i o n. - According to Hoedemaeker (2013), $B$. rotundatus occurs in the upper part of the Balearis Zone and in the Ohmi Zone. It is known from France, Spain, Switzerland Italy, Hungary, Georgia and the locality of Podbranč in Slovakia.

O c c u r r e n c e. $-B$. rotundatus occurs sporadically in both the sections in Na piate Quarry, namely in their higher parts.

\section{Angulicostatus Group}

$\mathrm{R}$ e $\mathrm{m}$ a r k s. - Flat whorls are not in contact. The early trituberculate stage with rather strong main ribs is to end at shell diameters of $16-23 \mathrm{~mm}$. After this stage, any part with thin, closely spaced, uniform ribs typical for the Binelli Group does not follow. Trituberculate main ribs may reach as far as the mouth in large shells.

\section{Binelliceras michalíki n. sp.}

(Figs. 6F and 7)

1983 Crioceratites (Crioceratites) nolani (Kilian); Adamíková et al.: p. 602 , pl. 1 , fig. 3

1983 Crioceratites (Crioceratites) emerici Léveillé; Adamíková et al.: p. 600 , pl. 2, fig. 2.

1995 Crioceratites "nolani" Adamíková et al., non Kilian; Hoedemaeker: p. 238, pl. 6, fig. 8 .

$\mathrm{Hol}$ oty pe. - An incomplete adult specimen (spec. SNM Z 38623)

Stratum typicum and locus typicus. Na piate Quarry, section at $250 \mathrm{~m}$, layer No. 5 near the boundary between the Balearis/Ohmi ammonite Zones (Late Hauterivian).

De rivation o minis. - In honour of Assoc. Prof. Jozef Michalík, Dr.Sc, who significantly contributed to the biostratigraphy and geology of the Western Carpathians.

D i a g n o s is. - Slightly uncoiled, rather large specimens. In the whole stage of growth, the main trituberculate ribs between which subsidiary ribs are inserted occur on the whole periphery. The lower number of inserted ribs on early whorls increases to 4-7 on adult ones.

$\mathrm{M}$ a t e ri a I. - Three slightly deformed, more or less incomplete sculpture moulds of adult shells (specs. SNM Z $38623,38614,38618$ ) with corroded juvenile and in some cases also corroded adult whorls. The most juvenile part of the first whorl is not preserved. According to the remains of sutures seen on accompanying material, the phragmocone ends at a diameter of $\sim 60 \mathrm{~mm}$.

D e s c r i p t i o n. - Moderately large to large, slightly uncoiled specimens with imperceptible vaulted flanks of whorls 


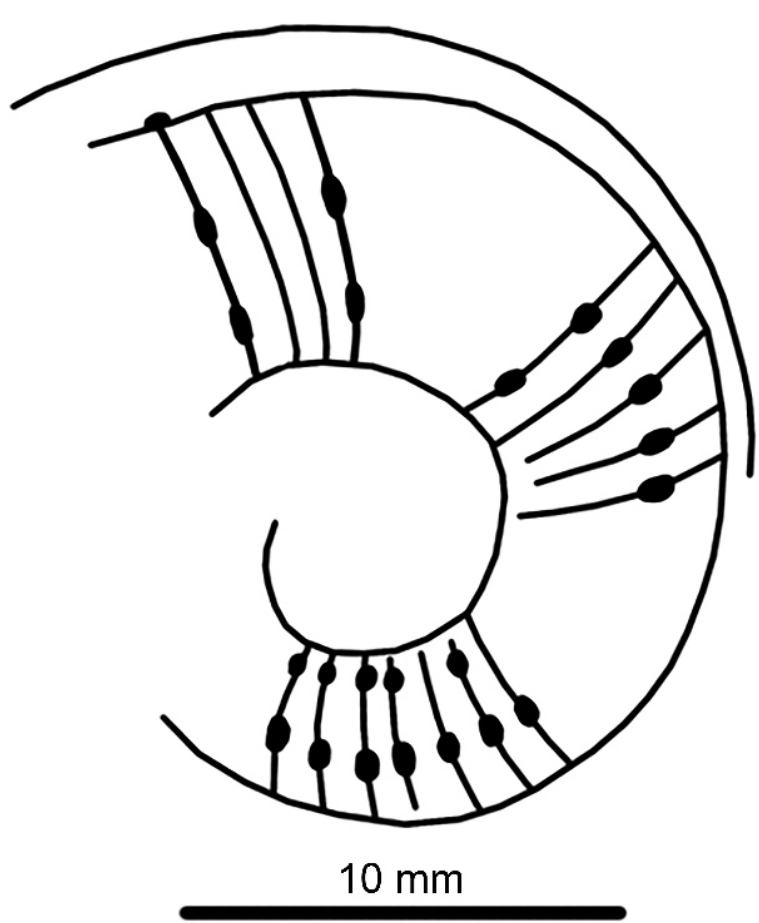

Fig. 7. Drawing of the juvenile whorl of the holotype Binelliceras michalíki n. sp., spec. SNM Z 38623

that gradually slope down to the ventre. The whorls have rather greater heights than is usual in related species.

The earliest sculpture is apparent at diameters of $4-5 \mathrm{~mm}$. In an ideal case, comparatively strong, simple trituberculate ribs with quite distinct lateral tubercles with weaker umbilical and ventrolateral tubercles are apparent. From a diameter of $\sim 5 \mathrm{~mm}$, between the pairs of ribs with strong lateral tubercles, 1 to 2 weaker ribs without tubercles or with a weak lateral tubercle occur. From a diameter of $\sim 13 \mathrm{~mm}$, the ribbing and tubercles seem to be weaker. Between the main ribs, two thinner inserted ribs without tubercles usually occur. At a diameter as small as $\sim 15 \mathrm{~mm}$, the number of inserted ribs may increase to 4-6. The ribs continue to be comparatively thin and closely spaced, tubercles less noticeable. There is fibulation in some places. From a diameter of $\sim 40 \mathrm{~mm}$, ribs generally strengthen and become widely spaced; tubercles strengthen as well. At a diameter of $\sim 70 \mathrm{~mm}$, ribs on the level of lateral tubercles are inclined towards the aperture. Between the trituberculate ribs, the number of inserted ribs occurring there is variable (usually 3 to 5 ). Some of these are shorter. In the vicinity of the ventre, some inserted ribs bifurcate.

At the end part of the largest shell (i.e. holotype of diameter ranging from 90 to $100 \mathrm{~mm}$ ), the number of inserted ribs grows to 5-7. Tubercles on the trituberculate main ribs are roughly equivalent. On the specimen largest in size (on the holotype), before the main ribs, there are shallow constrictions near the mouth.

M e a s u rement. - The largest specimen SNM Z 38623 (holotype) reaches a diameter of $\sim 100 \mathrm{~mm}$. On the holotype, which is somewhat affected by slight lateral deformation, altogether three diameters and parameters can be measured on a single the same complete radian:

$$
\mathrm{D}_{1}=73.0 \mathrm{~mm} \mathrm{H} \mathrm{H}_{1}=26.0(0.36) \quad U_{1}=31.8(0.42)
$$

$\mathrm{D}_{2}=46.5 \mathrm{~mm} \mathrm{H}=16.0(0.34) \quad \mathrm{U}_{2}=15.8(0.34)$

$\mathrm{D}_{3}=34.0 \mathrm{~mm} \mathrm{H}_{3}=14.5(0.43) \quad \mathrm{U}_{3}=12.3(0.36)$

Per half-whorl, there are 11-12 main ribs at the maximum shell diameter of $100 \mathrm{~mm}$; peripheral ribs are innumerable.

On specimen SNM Z 38614 at:

$\mathrm{D}_{1}=53.5 \mathrm{~mm} \mathrm{H}_{1}=21.2(0.40) \quad \mathrm{U}_{1}=21.3(0.40)$

$\mathrm{D}_{2}=33.0 \mathrm{~mm} \mathrm{H}=14.0(0.42) \quad \mathrm{U}_{2}=11.3(0.34)$

on the same ray.

On the incomplete slightly deformed specimen SNM Z 38618 (Dmax of about $95 \mathrm{~mm}$ ):

$\mathrm{D}_{1}=71.0 \mathrm{~mm} \mathrm{H} \mathrm{H}_{1}=26.0(0.36) \quad \mathrm{U}_{1}=29.0(0.41)$

$\mathrm{D}_{2}=50.5 \mathrm{~mm} \mathrm{H}_{2}=17.8(0.35) \quad \mathrm{U}_{2}=19.9(0.39)$

Per half-whorl at $D=71 \mathrm{~mm}$ there is 13 main ribs and $\sim 50$ peripheral ribs. Egression appears at a diameter of $\sim 50 \mathrm{~mm}$.

$\mathrm{R} \mathrm{e} \mathrm{m}$ a r k s. - One of the characteristic features of subtly uncoiled specimens of $B$. michalíki is a comparatively large size. A distinctive feature is also trituberculate main ribs occurring from the juvenile whorls to the mouth; this means, throughout the whole growth stage. On the final whorl, there are a comparatively high number of inserted ribs (4-7).

What is rather problematic is the genus assignation of the new species. From the point of view of its morphology and concept of crioceratid and pseudothurmanniid ammonites, the classification of $B$. michalíki to the Angulicostatus Group in the sense of Hoedemaeker (2013: p. 118) seems most suitable. According to the species composition stated by Hoedemaeker (2013), none of the species stated by him, however, corresponds to $B$. michaliki. With regard to the persistent trituberculate main ribs, it is closest to the holotype of Pseudothurmannia (Parathurmannia) edouardi (Honnorat-Bastide, 1889). On the plaster cast of this holotype, which we could study in the collection of Prof. Wiedmann at the University in Tübingen, no juvenile whorls up to a diameter of $\sim 30 \mathrm{~mm}$ are preserved. The earliest part of the specimen has a whorl at the beginning, preserved only incompletely. At its beginning, the number of inserted ribs (5-6) between trituberculate inserted ribs from a diameter of $\sim 50 \mathrm{~mm}$ drops only to $2-3$ ribs. Per half of this specimen of Parathurmannia edouardi there are $\sim 37$ peripheral ribs in contrast to 50 ribs in B. michalíki. Specific identification of both thus is not possible. However, with unknown juvenile whorls, it cannot be excluded that $P$. edouardi does not belong to the subgenus Parathurmannia, but to the genus Binelliceras, to the Angulicostatus Group.

One of specimens of $B$. michalíki was published earlier in Adamíková et al. (1983) under the name of Crioceratites (Crioceratites) nolani (Kilian). This was recorded by Hoedemaeker (1995). In a short description connected with the synonymy he stated that it was the case of a new species. In its synonymy it is stated that also Crioceras Picteti Nolan in Karakasch (1907, pl. 16, fig. 5 a-c and pl. 27, fig. 11) and further Crioceratites nolani Kilian in Drushchits and Kudryavtsev (1960, pl. 31, fig. 5) belong here. Based on the previous study of the collection of Karakasch in Petersburg and the collection of Drushchits in Moscow (Z.V.), it can be, however, stated that the specimens are not identical with $B$. michalíki.

$\mathrm{D}$ i s $\mathrm{r}$ i b u t i o n. - In addition to two Slovak localities ( $\mathrm{Na}$ piate Quarry and Kamenná Hill), the new species is known, according to Hoedemaeker's illustration (1995), from section W in the locality of Río Argos in Spain, Ohmi Zone.

$\mathrm{O}$ c c u r r e n c e. - The majority of findings of $B$. michaliki come from the Na piate Quarry from the section at $250 \mathrm{~m}$. The holotype as a single exactly localized find comes from layer No. 5 in this section (see Fig. 6F). Its stratigraphic range is probably slightly greater than shown in Figure 2 . 
Genus Pseudothurmannia Spath, 1923 1955.

T y p e s p e cies. - Pseudothurmannia picteti Sarkar,

R e m a rks. - Evolute to slightly crioconic whorls. The earliest ribs are simple and thin. Lateral tubercles are missing With growth, the ribs strengthen and become differentiated into main and inserted ribs. Between the pairs of the main ribs, there are usually 1 - 4 shorter ribs, seldom more. On the shoulders of each rib, there are small clavate ventrolateral tubercles.

Hoedemaeker (2013) divided the genus Pseudothurmannia into three subgenera: Pseudothurmannia, Parathurmannia Busnardo, 2003 and Kakabadziella Hoedemaeker, 2013.

Subgenus Pseudothurmannia (Kakabadziella) Hoedemaeker, 2013 1858.

T y p e s p e c i e s. - Ammonites Mortilleti Pictet et Loriol,

$\mathrm{R}$ e $\mathrm{m}$ a r k s. - The ribs are without lateral tubercles in all stages. Inner whorls with thin and dense ribbing of the balearis type. Differentiated main and subsidiary ribs are flexuous from the medium stage.

Pseudothurmannia (Kakabadziella) ohmi ohmi (Winkler, 1868) (Fig. 6G)

1860 Ammonites angulicostatus d'Orbigny; Ooster: p. 114, pl. 23, fig. 1, non figs. 2-3 (= Pseudothurmannia /Kakabadziella/ tornajensis Hoedemaeker, 2013), non fig. 4 (= Crioceratites sp.).

1868 Ammonites Ohmi Winkler: p. 6, pl. 1, fig. 8.

1955 Pseudothurmannia angulicostata Hyatt; Eristavi: p. 94, pl. 3, fig. 7.

1958 Psudothurmannia angulicostata (d'Orbigny); Luppov et Drushchits: p. 101, pl. 46, fig. 5.

1961 Pseudothurmannia angulicostata d'Orbigny; Eristavi: p. 97 , pl. 4 , fig. 4.

1994 Pseudothurmannia angulicostata (d’Orbigny); Vašíček et al.: p. 65 , 20, fig. 3.

2013 Pseudothurmannia (Kakabadziella) ohmi ohmi (Winkler); Hoedemaeker: p. 65 , figs. 32,33 , pl 15, figs. 1-6, pl. 16, figs. $1-4$, pl. 17 , figs. $1-8$, pl. 18 , figs. $1-7$, pl. 19 , figs. $1-18$, tab. 4 (cum syn.).

M a t e ri a I. - A sculpture mould with a favourably preserved final whorl (spec. SNM Z 21149) but without preserved inner whorls.

D e s c ription. - An evolutely coiled specimen, with whorls in contact, with the umbilicus that has a breadth greater than the height of the final whorl. The unfavourably preserved earliest sculpture begins only at a diameter of $\sim 22 \mathrm{~mm}$; the umbilical area is not preserved. At the very beginning of the final whorl affected by flat compression, where the maximal end of the specimen does not reach any more, two rows of slightly clavate ventrolateral tubercles are apparent on all ribs. There are short spines on the row of tubercles on the opposite side. At a diameter of $\sim 27 \mathrm{~mm}$, which could correspond, according to the character of the deformation of the specimen studied, to the vicinity of the end of phragmocone, stronger, S-shaped main ribs alternate with inserted ribs. The main ribs have periumbili- cal bulging at their bases. From a shell diameter of $\sim 30 \mathrm{~mm}$, all ribs strengthen. The main ribs begin at the umbilical turbecles. On the front side of the main ribs there is usually a constriction. The number of inserted ribs, which are of different lengths, can increase up to four; more frequently, the number is variable (1-3). Some of the ribs bifurcate at about half the height of the whorl, or higher.

M e a s u re me n t. - On specimen SNM Z 21149 at Dmax $=48.4 \mathrm{~mm}$, is $\mathrm{H}_{1}=17.8(0.37)$ and $U_{1}=19.4(0.40)$, at $D_{2}$ $=43 \mathrm{~mm}, \mathrm{H}_{2}=17.0(0.395)$ and $U_{2}=17.6(0.41)$. At the maximum shell diameter, there are 13-14 main ribs and 40 peripheral ribs per half-whorl. At $D_{2}$, there are 14 main ribs and 38 peripheral ribs per half-whorl.

$\mathrm{R}$ e $\mathrm{m}$ a r k s. - In spite of the lack of knowledge about the juvenile whorls of the Slovak specimen, based on all diagnostic features on the ultimate whorl, our assignation to P. (Kakabadziella) ohmi ohmi can be considered as justified. According to Hoedemaeker (2013), K. ohmi ohmi differs from $K$. ohmi valbonettensis only insignificantly, the latter subspecies having a lesser breadth of the umbilicus and finer, denser ribbing. A greater difference consists in the stratigraphic positions of the two subspecies.

In the synonymy of $K$. ohmi ohmi, there are two discrepancies in Hoedemaeker (2013: p. 65). In the synonymy, Crioceratites (Pseudothurmannia) belimelensis Dimitrova in Adamíková et al. (1983), which was later correctly assigned to Binelliceras krenkeli Sarkar (see Hoedemaeker, 2013: p. 112), is included; similarly, the specimen designated as Pseudothurmannia shankariae Sarkar in Vašíček (1989), which was considered by Hoedemaeker (2013: p. 102) to be Balearites theodomirensis Hoedemaeker in one part of the text and a variety of Balearites balearis (Nolan) in another. Herein, we consider $B$. shankariae to be an individual species.

$\mathrm{D}$ i s $\mathrm{t} \mathrm{r}$ i b u $\mathrm{t}$ i o n. - Kakabadziella ohmi ohmi is the eponymous species of the Ohmi ammonite Zone. The subspecies is known from France, Spain, Germany, Italy, Hungary, Bulgaria, Georgia.

O c c u r r e n c e. - Na piate Quarry, the uppermost part of the exposure at $260 \mathrm{~m}$, in the continuation of the section at $250 \mathrm{~m}$ (Ohmi Zone).

\section{DISCUSSION}

As follows from the many publications, the taxonomy of evolute and slightly developed shells included under the names of Crioceratites and Pseudothurmannia is complicated and unclear.

The recent monograph by Hoedemaeker (2013) includes what we consider to be a challenging approach to the taxonomy of these ammonites. The initial theme focused on the study of sculpture on juvenile whorls and observation of other changes in the course of shell growth. The data on egression stated by Hoedemaeker (2013) seem to us to be rather unconvincing. These data were obtained by measurement of a single diameter on each of the series of specimens (sorted by size). The measured values in Hoedemaeker (H/D, U/D) are, however, usually quite variable. We consider that this is the result of uneven preservation of shells, or of deformation. We think that egression, with reference to evolute or slightly developed shells, should be observed using as many as possible measurements on each shell, especially from juvenile diameters to the adult stage. Results should be then correlated with other individuals of the same species. Where possible, we made such measurements on our specimens. However, we had not sufficient individuals to carry out correlation. 
We tried to apply Hoedemaeker's conclusions to our similar material collected in the quarries on Polomec Hill. Most of our material belongs to Balearites and Binelliceras, which we regard, in contrast to Hoedemaeker (2013), as individual genera. Our study of Balearites shankariae, B. theodomirensis and $B$. oicasensis supports the idea that the juvenile sculpture of the genus Balearites begins with a short stage of uniform, thin, closely spaced, trituberculate ribs. But the lateral tubercles disappear early. The ribbing remains thin and dense; the ribs are gradually differentiated into main and subsidiary ribs. The main ribs begin with umbilical tubercles. On all ribs, if the condition of preservation allows, there are tiny ventrolateral tubercles. In the case of favourable preservation, very short spines lie on them. Hoedemaeker states evolute coiling for Balearites. Our material demonstrates that some species are slightly uncoiled, where the gap between the whorls is filled with short ventrolateral spines (see Figs. 3B and 6A, B). In the species $B$. theodomirensis, we assume sexual dimorphism (Fig. 5B, C).

The genus Binelliceras is also characterized by a trituberculate initial stage. At first, uniform trituberculate ribs in Binelliceras krenkeli, B. ibizensis and B. rotundatus are stronger and more widely spaced (Figs. $3 \mathrm{C}$ and $6 \mathrm{D}$ ) than in the genus Balearites. Lateral tubercles disappear in Binelliceras later than in Balearites. A stage of uniform, closely spaced and thin ribs follows. Some of these bear weak umbilical tubercles. At this stage and later, when the differentiation of the ribs into main and subsidiary ribs is apparent, fibulation is usually apparent. Under favourable conditions, there are preserved small ventrolateral tubercles on all ribs (Fig. 5B). They may be stronger on the main ribs than on the inserted ribs. Hoedemaeker (2013) designated ammonites with these features as Binelliceras, Binelli Group. From the features of the stated representatives of the genus Binelliceras, Binelliceras michalíki n. sp. differs in some respect. In this species, the initial trituberculate stage (Fig. 7) is not followed by a stage of uniform thin and closely spaced ribs without lateral tubercles, but lateral tubercles continue periodically further. In the case of B. michaliki, they are developed as far as the aperture of large adult shells. This feature corresponds to the group of ammonites designated by Hoedemaeker (2013) as Binelliceras, Angulicostatus Group. With regard to certain differences between the Binelli Group and the Angulicostatus Group, in our concept taking Binelliceras as an individual genus, it can be considered that the groups could correspond to subgenera, i.e. Binelliceras (Binelliceras) and e.g. Binelliceras (Anguliceras) n. sg.

In the case of the last subspecies described herein, Pseudothurmannia (Kakabadziella) ohmi ohmi, our specimen has not any preserved juvenile whorls that could show lateral tubercles. This specimen, described in Vašíček et al. (1994: p. 65 , pl. 20, fig. 3), based on comparison with the plaster cast of the holotype of Pseudothurmannia angulicostata (d'Orbigny, 1841), deposited with Prof. Wiedmann at the Tübingen University, was originally considered to be an equivalent of this species. Hoedemaeker (2013), however, demonstrated that it was P. (K.) ohmi ohmi.

\section{STRATIGRAPHY}

As, in the quarries on Polomec Hill, no continuous section showing the continual occurrence of pseudothurmanniid ammonites has been found; stratigraphic conclusions presented here are derived mainly based on data from published papers.
With reference to the published data regarding Late Hauterivian ammonite biostratigraphy (e.g., Vermeulen et al., 2002; Company et al., 2003, 2005; Vermeulen, 2004; Reboulet et al., 2014) and biostratigraphy and sequence stratigraphy (Hoedemaeker, 2002, 2003, 2013) with respect to the detailed stratigraphy of the sections studied, we have inclined to the adoption of the relatively simple ammonite zonation as proposed by Hoedemaeker (2013) for the Upper Hauterivian in the sections at Río Argos. This shows the following ammonite zones in sequence: Ligatus, Balearis, Ohmi and Catulloi.

The identified species described here can, from the stratigraphic point of view, be divided into three to four time periods (Fig. 2). The oldest part is represented by the occurrence of Balearites balearis and $B$. shankariae from the section on level IV. The findings indicate the lower part of the Balearis Zone.

The second group consists of occurrences connected with the lower parts of the sections on level $\mathrm{V}$ at $250 \mathrm{~m}$ and $500 \mathrm{~m}$ (Fig. 2). They comprise Balearites theodomirensis, $B$. oicasensis, Binelliceras ibizensis and B. michalíki n. sp.; the occurrence of $B$. krenkeli begins here. $B$. michalíki probably continues higher - according to Hoedemaeker (2013), it occurs in the upper part of the Balearis Zone. B. theodomirensis, $B$. ibizensis and B. krenkeli are also present in the Ohmi Zone. Hence, the lower parts of the sections on level $\mathrm{V}$ likely belong to the upper part of the Balearis Zone.

Binelliceras krenkeli and $B$. rotundatus occur in the upper part of the sections on level V. We assume that this part belongs already to the Ohmi Zone. A single found index specimen, documenting the Ohmi Zone, is Kakabadziella ohmi ohmi. It comes from the closely overlying rocks of the section at $250 \mathrm{~m}$, namely from the exposure at $260 \mathrm{~m}$.

No other pseudothurmanniid representatives of the topmost Hauterivian, especially belonging to the genus Pseudothurmannia, were found by us, either in the strata overlying the ammonite-bearing sections on Polomec Hill, or in other localities of the Central Western Carpathians, even though sedimentation between the Hauterivian and the Barremian had evidently continued. We thus did not manage to document the uppermost zone of the Upper Hauterivian, i.e. Catulloi Zone, by suitable ammonites. Previous ideas (e.g., Vašíček et al., 1994) that, in the strata near Lietavská Lúčka, pseudothurmanniid ammonites document the whole of the Hauterivian, thus do not correspond to reality.

A hypothetical model of bathymetric conditions in the period of the sedimentation of the so-called pseudothurmanniid layers in the Upper Hauterivian has been made by Adamíková et al. (1983, see fig. 7). Deposits 8-9 m thick with abundant ammonites are designated in a sketch as the Pseudothurmannia Horizon. The sediments were deposited on a continental slope a little below the ACD-level.

After sinking of ammonite shells onto the bottom surface, the specimens were briefly exposed to erosion, though the sedimentation rate was sufficiently high for burial. Internal cavities of juvenile whorls after burial were partially filled with pyrite, being limonitized later. This considerable accumulation of nectic cephalopods was affected by the flow regime; most specimens reach shell sizes ranging from $\sim 40$ to $\sim 50 \mathrm{~mm}$, corresponding to sorting by size on a continental slope, while slump layers occur in the closely underlying beds.

However, a similar type of the sedimentation did not continuein area of Lietavská Lúčka, although deposits of the uppermost Hauterivian (Catulloi Zone) from classical areas are characterised by the abundant occurrence of representatives of all three subgenera of the genus Pseudothurmannia. Many of them are characterized by shells with large diameter and rather robust ribbing. 
The end of the Hauterivian in many parts of the Tethys Ocean in Europe was affected by changes in sedimentation. This is shown by studies of carbon isotope stratigraphy (e.g., Weissert et al., 1998; Godet et al., 2006), biostratigraphy, sedimentology and sequence stratigraphy (e.g., Cecca et al. 1994; Baudin et al., 1999; Baudin, 2005; Bodin et al., 2006; Hoedemaeker, 2002, 2013). In the Upper Hauterivian at the end of Ohmi Zone, in the area of the northern Tethyan margin, a Highstand Systems Tract often completes the Faraoni anoxic oceanic event or level. The following deposits (Catulloi Zone) represent a Lowstand Systems Tract. This period in Tethys was also accompanied by platform drowning episodes. These events were apparently not reflected in the Central Western Carpathians on the northern rim of the sedimentation area of the Fatricum Unit, to which the studied sections belong. Changes in the configuration of the sedimentation area on the northern Tethyan margin and probably corresponding tectonic movements led in the area of the Fatricum Unit to changes in the flow regime. The carbonate sedimentation further continued without any substantional change, but the supply of pseudothurmanniid ammonites at the beginning of the Catulloi Zone was interrupted.

\section{CONCLUSIONS}

In the taxonomic part of the submitted paper, 9 species of Late Hauterivian pseudothurmanniid ammonites are described in detail. One of them, Binelliceras michalikin. sp., is new. In the species Balearites theodomirensis, sexual dimorphism was found.

Ammonite-bearing deposits in the locality studied were formed on a continental slope closely below the ACD-level. Shells are sorted by size; most of them have diameters from $40 \mathrm{~mm}$ to $50 \mathrm{~mm}$.

The species of pseudothurmanniid ammonites identified demonstrate that on Polomec Hill near Lietavská Lúčka, the Balearis and Ohmi ammonite zones are recorded. In the uppermost Hauterivian, in the Catulloi Zone, pseudothurmanniid ammonites occur neither near Lietavská Lúčka, nor at other Slovak localities, although in the majority of localities in the Tethyan area their development still continues.

The absence of pseudothurmanniid ammonites in the Slovak localities in the topmost Hauterivian, connected with the events that are documented in the area of the northern Tethyan margin in Southern and Western Europe, is most probably connected with a change of the flow regime in the Fatricum Unit. It was the flow regime that ended the drift of the pseudothurmaniid ammonites into the sedimentation area studied.

Acknowledgements. We express our thanks K. Mezihoráková (Ostrava) for most of the photographs. The present paper has been supported by the Project for Long-Term Development of the Institute of Geonics, Czech Academy of Sciences. The authors thank the reviewers I. Ploch and especially $\mathrm{K}$. Bąk for their constructive recommendations.

\section{REFERENCES}

Adamíková, G., Michalík, J., Vašíček, Z., 1983. Composition and ecology of the "Pseudothurmannia-fauna", Lower Barremian of the Križna Nappe in the Strážovské Vrchy Mts. Geologický Zborník - Geologica Carpathica, 34: 591-615.

Arkell, W.J., Furnish, W.M., Kummel, B., Miller, A.K, Moore, R.C., Schindewolf, O.H., Sylvester-Bradley, P.C., Wright, C.W., 1957. Cephalopoda, Ammonoidea. In: Treatise on Invertebrate Paleontology (ed. R.C. Moore), part L, Mollusca 4: 1-490. Geological Society of America and University of Kansas Press.

Astier, J.-E., 1851. Catalogue descriptif des Ancyloceras appartenant à l'étage Néocomien d'Escragnolles et des Basses Alpes. Annales des Sciences Physiques et Naturelles, d'Agriculture et d'Industrie, 2: 435-456.

Autran, G., 1993. L'évolution de la marge nord-est provençale (Arc de Castellane) du Valanginian moyen à l'Hauterivien à travers l'analyse biostratigraphique des séries de la région de Peyroules: séries condensées, discontinuités et indices d'une tectogénèse distensive. Paléobiologie. Annales du Museum d'histoire Naturelle de Nice, 10: 1-239.

Avram, E., 1995. Lower Cretaceous (Valanginian-early Aptian) ammonite succession in the Sviniţa region (SW Rumania) Géologie Alpine, Mémoire Hors Série, 20 (1994): 113-167.

Baudin, F., 2005. A Late Hauterivian short-lived anoxic event in the Mediterranean Tethys: the "Faraoni Event". Comptes Rendus Geoscience, 337: 1532-1540

Baudin, F., Bulot, L.-G., Cecca, F., Coccioni, R., Gardin, S., Renard, M., 1999. Un équivalent du "Niveau Faraoni" dans le bassin du sud-est de la France, indice possible d'un événement anoxique fini-hauterivien étendu à la Téthys méditerranéenne. Bulletin de la Société géologique de France, 170: 487-498.
Bodin, S., Godet A., Vermeulen, J., Linder P., Föllmi, K.B., 2006. Biostratigraphy, sedimentology and semence stratigraphy of the latest Hauterivian-Early Barremian browning episode of the Northern Tethyan margin (Altmann Member, Helvetic nappes, Switzerland). Eclogae geologicae Helvetiae, 99: 157-174.

Borza, K., Michalík, J., Gašparíková, V., Vašíček, Z., 1984. The biostratigarphy of the Hauterivian/Barremian boundary beds in the Križna Nappe, Western Carpathians (Czechoslovakia). Cretaceous Research, 5: 349-356.

Busnardo, R., 2003. Ammonites et biostratigraphie du Crétacé inférieur de la Veveyse de Châtel. Revue de Paléobiologie, 22: $1-174$.

Cecca, F., Marini, A., Pallini, G., Baudin, F., Begouen V., 1994. A guide-level of the uppermost Hauterivian (Lower Cretaceous) in the pelagic succession of Umbria-Marche Apennines (Central Italy): the Faraoni Level. Rivista Italiana di Paleontologia e Stratigrafia, 99: 551-568.

Company, M., Sandoval, J., Tavera, J.M., 2003. Ammonite biostratigraphy of the uppermost Hauterivian in the Betic Cordillera (SE Spain). Geobios, 36: 685-694.

Company, M., Aguado, R., Sandoval, J., Tavera, J.M., 2005. Biotic changes linked to a minor anoxic event (Faraoni Level, latest Hauterivian, Early Cretaceous). Palaeogeography, Palaeoclimatology, Palaeoecology, 224: 186-199.

Dimitrova, N., 1967. IV. Crétacé inférieur, Cephalopoda (Nautiloidea et Ammonoidea). In: Les fossiles de Bulgarie (ed. V. Tzankov): 1-424. Bolgarska Akademiya na naukitike, Sofia.

Drushchits, V.V., Kudryavtsev, M.P., 1960. Atlas nizhnemelovoy fauny severnogo Kavkaza i Kryma (in Russian). Trudy: 1-396. Glavnoe Upravlenie gazovoy Promyshlennosti pri sovete 
ministrov SSSR; Vsesoyuznyi Nauchno-Issledovatel'skiy Institut prirodnykh Gazov (VNIIGaz), Moskva.

Eristavi, M.S., 1955. Nizhnemelovaya fauna Gruzii (in Russian). Institut Geologii i Mineralogii, Akademiya Nauk Gruzinskoi SSR, Monografii, 6: 1-225.

Eristavi, M.S., 1961. Nekotorye nizhnemelovye golovonogie Central'nych Karpat (in Russian). Geologické Práce, 21: 81-108.

Fülöp, J., 1964. A Bakonyhegység also-Kreda (Berriázi-Apti) képzödményei (in Hungarian). Geologica Hungarica, Series Geologica, 13: 6-193.

Gill, T., 1871. Arrangement of the families of Mollusks. Smithsonian Miscellaneous Collections, 227: 1-49.

Godet, A., Bodin, S., Föllmi, K.B., Vermeulen, J., Gardin, S., Fiet, N., Adatte, T., Berner, Z., Stüben, D., van de Schootbrugge, B., 2006. Evolution of the marine stable carbon-isotope rekord during the early Cretaceous: a focus on the late Hauterivian and Barremian in the Tethyan realm. Earth and Planetary Science Letters, 242: 254-271.

Hoedemaeker, Ph.J., 1995. Ammonite distribution around the Hauterivian-Barremian boundary along the Río Argos (Caravaca, SE Spain). Géologie Alpine, Mémoire Hors Série, 20: 219-277.

Hoedemaeker, Ph.J., 2002. Correlating the uncorrelatables: a Tethyan-Boreal correlation of pre-Aptian Cretaceous strata. In: Tethyan/Boreal Cretaceous Correlation. Mediterranean and Boreal Cretaceous palaeobiogeographic areas in Central and Eastern Europe (ed. J. Michalík): 235-285. Publishing House of the Slovak Academy of Sciences, Bratislava.

Hoedemaeker, Ph.J., 2003. Correlation of Tethyan and Boreal Berriasian-Barremian strata with emphasis on strata in the subsurface of the Netherlands. Cretaceous Research, 24: 253-275.

Hoedemaeker, Ph.J., 2013. Genus Pseudothurmannia Spath 1923 and related subgenera Crioceratites (Balearites) Sarkar, 1954 and C. (Binelliceras) Sarkar, 1977 (Lower Cretaceous Ammonoidea). Revue de Paléobiologie, 32: 1-209.

Honnorat-Bastide, E.-F., 1889. Sur une forme nouvelle de Crioceras du Crétacé inférieur des Basses-Alpes., Crioceras edouardi nov. sp. Association française des Advancements des Sciences, Congrès Paris, 2e partie: 462-464.

Immel, H., 1978. Die Crioceratiten (Ancyloceratina, Ammonoidea) des mediterranen und borealen Hauterive-Barreme (Unterkreide). Palaeontographica A, 163: 1-85.

Kakabadze, I.M., 2004. Predstaviteli rodov Pseudothurmannia Spath, 1923 i Simbirskites Pavlow, 1892 iz verkhnego goteriva Zapadnoi Gruzii (in Russian). Trudy Akademii Nauk Gruzii, Geologicheskii Institut im. A.I. Dzhanelidze, Novaya seriya, 119: 380-391.

Kakabadze, I.M., 2005. Rod Pseudothurmannia Spath, 1923 (in Russian). In: Atlas rannemelovoi fauny Gruzii, Otryad Ancyloceratida (ed. M.V. Topchishvili). Trudy Akademii Nauk Gruzii, Geologicheskii Institut im. A.I. Dzhanelidze, Novaya seriya, 120: 349-352.

Kakabadze, M.V., 1981. Antsiloceratidy yuga SSSR i ikh stratigraficheskoe znachenie (in Russian). Trudy Akademil Nauk Gruzinskoi SSR, Geologicheskii Institut im. A.I. Dzhanelidze, Novaya seriya, 71: 1-196.

Karakasch, N.I, 1907. Le Crétacé inférieur de la Crimée et sa faune. Travaux de la Société Impériale des Naturalistes de St.-Petersbourg, 32: 1-484.

Léveillé, C., 1837. Description des quelques nouvelles coquilles fossiles du département des Basses-Alpes. Mémoire de la Société géologique de France, 10: 313-315.

Luppov, N.P., Drushchits, V.V., 1958. Mollyuski - golovonogie II (ceratity, ammonity), vnutrennerakovinnye. Prilozhenie konikonchii. In: Osnovy paleontologii (ed. Yu. A. Orlov): 1-322, Moskva.

Nolan, H., 1894. Note sur les Crioceras du groupe du Crioceras Duvali. Bulletin de la Société géologique de France, Série 3, 22: 183-196.

Ooster, W.,A., 1860. Catalogue des Céphalopodes fossiles des Alpes suisses avec la description et les figures des espèces remarquables. Partie 4, Céphalopodes tentaculifères, ammonitides, G. Ammonites: 1-160; Partie 5, Céphalopodes tentaculifères, ammonitides, G. Scaphites etc.: 1-100.

Orbigny, A. d', 1841. Paléontologie française. Description zoologique et géologique de tous les animaux mollusques et rayonnés fossiles de France. Terrains Crétacés. 1, Céphalopodes: 121-430. D'Orbigny and Arthus-Bertrand, Paris.

Reboulet, S., Szives, O., Aguirre-Urreta, B., Barragán, R, Company, M. Idakieva, V., Ivanov, M., Kakabadze, M.V., Moreno-Bedmar, J.A., Sandoval, J., Baraboshkin, E.J. et al., 2014. Report on the 5th International Meeting of the IUGS Lower Cretcaeous Ammonite Working Group, the Kilian Group (Ankara, Turkey, 31st August 2013). Cretaceous Research, 50: 126-137.

Rodighiero, A., 1919. II sistema Cretaceo del Veneto Occidentale compreso fra l'Adige e il Piave noc speciale riguardo al Neocomiano dei Sette Comuni (in Italian). Palaeontographica Italica, 25: 39-126.

Sarasin, Ch., Schöndelmayer, Ch., 1901. Étude monographique des ammonites du Crétacé inférieur de Chatel-Saint Denis. Première Partie, 28: 1-91.

Sarkar, S.S., 1954. Sur une genre nouveau d'ammonites déroulées. Compte Rendu sommaire de la Société géologique de France, (1954): 97-98.

Sarkar, S.S., 1955. Révision des ammonites déroulées du Crétacé inférieur du sud-est de la France. Mémoires de la Société geologique de France, Nouvelle Série, Mémoire, 72: 5-176.

Sarkar, S.S., 1977. Sur Binelliceras genre nouveau d'Heteromorpha et sur la validité du genre Emericiceras Sarkar, 1954. Paläontologische Zeitschrift, 51: 258-261.

Spath, L.F., 1923. A monograph of the ammonoidea of the Gault, 1, part 1. Palaeontographical Society (1921): 1-72.

Thomel, G., 1964. Contribution à la connaisance des céphalopodes Crétacés du sud-est de la France; note sur les ammonites déroulées du Crétacé inférieur vocontien. Mémoire de la Société géologique de France, Nouvelle Série, Mémoire, 101: $1-80$.

Vašíček, Z. 1989. Heteromorfní amoniti spodnokřídových souvrství Centrálních Karpat Slovenska. Zborník z paleontologické konferencie, Geologický Ústav Dionýza Štúra: 117-120.

Vašíček, Z., 1995. Lower Cretaceous ammonite biostratigraphy in the Western Carpathians (the Czech and Slovak Republics). Géologie Alpine, Mémoire Hors Série, 20 (1994): 169-189.

Vašíček, Z., 1997. Ammonite stratigraphy of the pre-Albian Lower Cretaceous formations of the Western Carpathians (Czech and Slovak Republics). Geologica Carpathica, 48: 231-242.

Vašíček, Z., 2002. Lower Cretaceous Ammonoidea in the Podbranč Quarry (Pieniny Klippen Belt, Slovakia). Bulletin of the Czech Geological Survey, 77: 187-200.

Vašíček, Z., Michalík, J., 1988. Some heteromorphic ammonites from Polomec (Hauterivian - Barremian, Central Western Carpathians, Czechoslovakia). Geologický Zborník - Geologica Carpathica, 39: 655-674.

Vašíček, Z., Michalík, J., Reháková, D., 1994. Early Cretaceous stratigraphy, palaeogeography and life in Western Carpathians. Beringeria, 10: 3-169.

Vašíček, Z., Rabrenović, D. Radulović, V., Radulović, B., 2009. Late Valanginian-Hauterivian cephalopod fauna from the Stara Planina Mountain (Eastern Serbia). Neues Jahrbuch für Geologie und Paläontologie, Abhandlungen, 251: 129-145.

Vermeulen, J., 2004. Vers une nouvelle classification à fondement phylogénétique des ammonites hetéromorphes du Crétacé inférieur méditerranéen. Riviéra Scientifique, 88: 69-92.

Vermeulen, J., Bert, D., Autran, G., 2002. Eléments pour la biostratigraphie ammonitique de l'Hauterivien terminal méditerranéen. Riviéra Scientifique, 86: 71-87.

Vermeulen, J., Duyé, J.-P., Lazarin, P., Leroy, L., Mascarelli, E., 2009. Nouvelles donnees taxinomiques sur la famille des Crioceratitidae Gill, 1871 (Ancyloceratina, Ancyloceratoidea). Riviéra Scientifique, 92: 65-76. 
Weissert, H., Lini, A., Föllmi, K.B., Kuhn, O., 1998. Correlation of Early Cretaceous carbon isotope stratigraphy and platform browning events: a possible link? Palaeogeography, Palaeoclimatology, Palaeoecology, 137: 189-203.

Wiedmann, J., 1962. Unterkreide-Ammoniten von Mallorca. 1. Lieferung: Lytoceratina, Aptychi. Akademie der Wissenschaften und Literatur, Abhandlungen der mathematisch-naturwissenschaftlichen Klasse, 1: 1-148.

Wiedmann, J., 1966. Stammesgeschichte und System der posttriadischen Ammonoideen, ein Überblick (2. Teil). Neues
Jahrbuch für Geologie und Paläontologie, Abhandlungen, 127: 13-81.

Winkler, G.G., 1868. Die Neocomformation des Urschlauerachenthales bei Traunstein mit Rücksicht auf ihre Grenzschichten. Versteinerungen aus dem bayerischen Alpengebiet mit geognostischen Erläuterungen, 1-48. Verlag der J. Lindauer'schen Buchhandlung, München.

Wright, C.W., Callomon, J.H., Howarth, M.K., 1996. Cretaceous Ammonoidea. Treatise on Invertebrate Paleontology, Part L, Mollusca 4 (revised), 1-362. Boulder \& Lawrence (Geological Society of America \& University of Kansas Press). 